\title{
Citizenship, Fertility, and Parental Investments
}

\author{
By Ciro Avitabile, Irma Clots-Figueras, and Paolo Masella*
}

Citizenship rights are associated with better economic opportunities for immigrants. This paper studies how in a country with a large fraction of temporary migrants the fertility decisions of foreign citizens respond to a change in the rules that regulate child legal status at birth. The introduction of birthright citizenship in Germany in 2000, represented a positive shock to the returns to investment in child human capital. Consistent with Becker's "quality-quantity" model of fertility, we find that birthright citizenship leads to a reduction in immigrant fertility and an improvement in health and socio-emotional outcomes for the children affected by the reform. (JEL J13, J15, J16, J24)

M igration policies can have a significant impact on immigrants' opportunities in the host country. When entitled to citizenship, immigrants are both more likely to perform better in the labor market and be more integrated into the native culture. This paper exploits the introduction of birthright citizenship in Germany to isolate the effect of legal status at birth on immigrants' fertility decisions and to test whether the behavioral responses we observe are consistent with the predictions provided by the theoretical literature.

Evidence from many Western countries shows that immigrant women, on average, have more children than the natives. Although the difference has declined in recent years, mostly as a consequence of the generalized drop in fertility (see Blau et al. 2008 for the United States and Mayer and Riphahn 2000 for Germany), the gap between immigrants' and natives' fertility is wide. These differential fertility patterns are often perceived as a threat to local traditional values and national identity not only by the public opinion, but also by politicians (Sarrazin 2010) and scholars (Huntington 2004).

In this paper, we show how a particular migration policy, namely the German citizenship law, affects immigrants' fertility choices. With the 2000 nationality law,

\footnotetext{
*Avitabile: World Bank Group and CSEF, 1818 H Street, N.W., Washington, DC 20433 (e-mail: cavitabile@ worldbank.org); Clots-Figueras: Universidad Carlos III de Madrid, Departamento de Economia C/ Madrid 126 28903 Getafe (Madrid) (e-mail: iclots@eco.uc3m.es); Masella: University of Sussex, Department of Economics Jubilee Building Jub-27 (e-mail: pm295@sussex.ac.uk). The authors are grateful for valuable comments and discussion to David Card, Rajeev Dehejia, Rafael Lalive, Fabian Lange, Marco Manacorda, Barbara Petrongolo, Uwe Sunde, Michele Tertilt, John van Reenen, Marcos Vera Hernandez, Ernst-Ludwig von Thadden, Andrea Weber, and seminar participants at Universidad Carlos III de Madrid, Universita' di Napoli "Federico II," University of Mannheim, London School of Economics, Queen Mary University, University of California at Berkeley, Stanford University, CEMFI, University of Modena, University of Lausanne, University of Bristol, Bocconi University, University of Southampton, University of Surrey, and University of Sussex. Irma Clots-Figueras gratefully acknowledges financial support from SEJ2007-67436 and ECO2011-29672.

${ }^{\dagger}$ Go to http://dx.doi.org/10.1257/app.6.4.35 to visit the article page for additional materials and author disclosure statement(s) or to comment in the online discussion forum.
} 
Germany shifted from a right of blood to a birthright system. ${ }^{1}$ Before 2000 , the children of immigrants could acquire German citizenship through naturalization at the age of 18, upon complying with the requirement of 8 years of residency in Germany, and after relinquishing their parents' citizenship. After 2000, children born to immigrant parents are granted German citizenship at birth if at least 1 parent has legally resided in Germany for at least 8 years, and are allowed to maintain dual citizenship up to the age of 23 .

Citizenship provides unrestricted access to the host country labor market, and evidence from many countries shows that immigrants who naturalize earn more than those who do not. ${ }^{2}$ Nevertheless, immigrants often do not take advantage of the possibility to naturalize, since this requires them to relinquish their former citizenship in many countries. ${ }^{3}$ Under the new regime, immigrants' children born in Germany (unlike their parents) have an extended period of time to enjoy dual citizenship and to decide which country's citizenship to adopt.

Even if willing to relinquish their former citizenship, some immigrants might find the residence requirements for naturalization too difficult to meet. Many migrate only for a limited period of time, and temporary (as opposed to permanent) migration has increased over time. ${ }^{4}$ Uncertainty about the length of stay in the host country is therefore likely to affect parental perceptions about the ability of their children to comply with the naturalization requirements. While returns on schooling and health investments are higher for citizen than noncitizen children, children's failure to meet the naturalization requirements would reduce parental incentives to invest in their human capital. Under the birthright system, parents' return plans have no effect on the newborn child's legal status.

In the standard "quality-quantity" (Q-Q) framework (see Becker and Lewis 1973; Becker and Tomes 1976) citizenship at birth can be interpreted as a reduction in the price of child "quality." The shock driven by citizenship acquisition should translate into an improvement in the child "quality" level and ultimately a decrease in the optimal number of children, since an increase in quality causes a rise of the shadow price of quantity. . $^{-}$

In the first part of this paper, we study how the legal status of prospective children affects immigrants' fertility. In order to identify the effect of birthright citizenship,

\footnotetext{
${ }^{1}$ Bertocchi and Strozzi (2010) provide an extensive analysis of the determinants and the evolution of citizenship laws in the post-World War II period.

${ }^{2}$ See Bratsberg, Ragan, and Nasir (2002) for the US, DeVoretz and Pivnenko (2004) for Canada, and Bevelander and Veenman (2006) for the Netherlands. Fougere and Safi (2009) finds that naturalized immigrants in France are more likely to find a job than nonnaturalized ones. Steinhardt (2008) finds that average wages for naturalized immigrants in Germany are 6 percent higher than the wages paid to foreign workers. His findings also show that naturalization leads to an immediate increase in wages, and also to higher returns from work experience.

${ }^{3}$ Mazzolari (2009) shows, for the United States, that immigrants from five Latin American countries were significantly more likely to naturalize after their home-country governments allowed for dual citizenship and, as a result, improved their labor market outcomes.

${ }^{4}$ In 2006, for example, the Organisation for Economic Co-operation and Development (OECD) countries received 2.5 million temporary migrants, about three times the number of permanent migrants (Dumont 2008).

${ }^{5}$ Becoming a citizen at birth might represent not just an economic shock; immigrants might perceive that natives are more willing to accept their citizen children, and, as a consequence, might decide to assimilate more. A recent strand of literature emphasizes the role of cultural traits as an important determinant of fertility behavior (see, among others, Fernandez and Fogli 2009 and Almond, Edlund, and Milligan 2009). Therefore, a reduction in fertility might reflect cultural convergence of immigrants to natives' patterns.
} 
we exploit the main provision of the law passed by the German Parliament in May 1999: a child born to foreign parents on January 1, 2000 or after, is granted citizenship at birth if at least one parent has been ordinarily resident in Germany for at least eight years. In this setting, households composed of foreign parents who have resided in Germany for eight or more years represent the treatment group. We can define two comparison groups: the first includes all households where there is only one foreign parent, the second includes all households where there is no foreign parent. By comparing the fertility behavior of households in the treatment group with those in the two comparison groups, before and after the reform, in a standard difference-in-differences specification, we can identify how the introduction of birthright citizenship affects fertility.

Our results suggest a negative and significant effect of birthright citizenship on immigrants' fertility. In households affected by the reform, the fertility—as defined by the probability of having a child born within the last 12 months - drops by 7 percent of a standard deviation. In order to test whether the introduction of citizenship at birth is associated with an improvement in child quality, we study whether children affected by the reform display better health and socio-emotional outcomes. We find that the obesity gap between noncitizens' and citizens' children at preschool age drops significantly for children born in 2000 or immediately afterward, compared to those born immediately before 2000 . Our results also show that children affected by the reform display better noncognitive development outcomes.

There are different ways through which immigrant parents might contribute to improve their children's quality. For instance, parents might change their saving/consumption decisions, increasing child related expenditure. They might decide to move to less segregated residential areas, where their children can attend better schools and have closer connections with German natives. Parents might also decide to improve their own levels of assimilation within the German culture, thus reducing the assimilation cost for their children. Finally, parents might change their time allocation decisions, devoting more attention to their children. We find some suggestive evidence to support the last mechanism, as we find that mothers of children affected by the reform reduce their labor supply and spend more time taking care of their children.

To our knowledge this is the first paper to provide quantitative evidence on the effect of migration policies on immigrants' fertility. We contribute to the recent strand in the economic literature on the effect of legal status on individual behavior. Avitabile, Clots-Figueras, and Masella (2013), based on another provision of the 2000 German nationality law, find that a change in child legal status increased the propensity of parents to engage in social contacts with Germans and use the German language. The present study adds to this literature showing that child legal status at birth not only affects attitudes but also affects the economically relevant behavior of parents. ${ }^{6}$

The paper is organized as follows. In Section I, we describe the German nationality reform and outline the benefits of German citizenship, then we discuss two simple theoretical frameworks. In Section II, we present the empirical strategy and the data. In Section III, we report the main results for fertility and discuss potential

\footnotetext{
${ }^{6}$ Mastrobuoni and Pinotti (2010) argue that crime rates among Romanian immigrants in Italy decreased as a result of the economic opportunities related to their new status as EU citizens.
} 
confoundings. In Section IV, we provide evidence that cohorts of immigrants children affected by the reform display better health and socio-emotional outcomes. In Section V, we provide a discussion of our results. Section VI concludes.

\section{Background}

\section{A. The German Nationality Reform}

In May 1999, the German Parliament amended the Citizenship and Nationality Law of 1913. The main objective of the reform was the introduction of birthright citizenship for children born in Germany to foreign parents, but the law also introduced changes to the naturalization criteria and explicitly denied dual citizenship for immigrants who naturalize. In this paper, the main focus is on the introduction of birthright citizenship, although we test whether the other provisions affect our results.

Before the reform, a child born in Germany was granted German citizenship at birth only if at least one parent was a German citizen at the time of its birth.7 Under the new regime, a child born in Germany to foreign parents on January 1, 2000 or after is granted citizenship at birth if two conditions are satisfied: (i) at least one parent has been ordinarily resident in Germany for eight years, and (ii) if at least one parent has been granted permanent right of residence. The child is then granted dual citizenship up to the age of 23 , when he or she must decide which to retain. This is known as the Options modell. ${ }^{8}$ This clause represented an exception under the framework introduced by the new nationality law that explicitly denied dual citizenship. Under the old regime dual citizenship was not legally recognized and granted only on a discretionary basis. Anil (2006) reports anecdotal evidence suggesting that the German officialdom generally was unwilling to entertain the idea of dual citizenship.

Unlike the citizenship at birth provision, the policy for naturalization for adults underwent various changes in the years before the reform. Laws affecting naturalization applications were passed in 1990 and 1993. The changes involved limited discretion of officials to deny naturalization, and foreigners' legal rights to claim entitlement to naturalization. After 1993, foreigners aged between 16 and 23 years with 8 or more years of residency, and foreigners over the age of 23 with a minimum of 15 years of residency, had a legal claim to naturalization. From 2000 onward, the requirement became eight years also for the older age group, but naturalization was no longer based exclusively on residence. Applicants for naturalization were required also to: express loyalty to the German Constitution, be able to support themselves and their family without social security or unemployment benefits, have a clean criminal record, have proven adequate command of the German language, and renounce former citizenship.

\footnotetext{
${ }^{7}$ In the case that only the father was a German citizen, citizenship was dependent on recognition or determination of paternity under German law.

${ }^{8}$ The reform also includes a transitional provision for children aged under ten years on January 1, 2000 with foreign parents. These children were granted naturalization upon application (to be completed before December 31, 2000) if at least one parent had been ordinarily resident in Germany for at least eight years at the time of the child's birth.
} 


\section{B. The Benefits of German Citizenship at Birth}

This section describes the benefits of German citizenship and analyzes the advantages of its being granted at birth rather than later in life. First, obtaining a German passport has labor market benefits. In Germany, there are several careers that require ownership of a German passport. ${ }^{9}$ There are also restrictions on access to careers in other administrative departments, but most do not apply to EU citizens..$^{10}$ Steinhardt (2008) provides evidence that naturalized immigrants are more likely to be employed in white collar occupations. In addition, the possibility to travel without restriction within the EU has significantly increased the advantages of an EU passport for individuals employed in occupations that require unrestricted mobility and no bureaucratic hurdles. Employment of EU citizens often leads to a reduction in the costs to employers, as there is no need for visas or other special administrative permits. Obtaining a German passport has some other noneconomic benefits. As in most countries, citizenship endows the right to vote in general and in local elections. Other advantages include the possibility to obtain visas for relatives and legal protection in the case of criminal charges.

To the best of our knowledge, acquiring German citizenship does not provide immigrants with better access to the main welfare programs. For instance, citizenship status does not affect the eligibility criteria for insurance-based unemployment benefits and unemployment assistance. Eligibility for social assistance is also independent of citizenship (Riphahn, Sander, and Wunder 2013). Similarly, there are no differences between citizens and noncitizens in the rules that regulate access to healthcare, kindergartens, and child daycare centers (Federal Office for Migration and Refugees in Germany).

Before the introduction of the nationality law in 2000, German citizenship could be obtained through naturalization, marriage, or adoption, the first one being the most common route. The award of citizenship at birth rather than through naturalization as an adult has three main advantages: (i) the possibility to hold dual citizenship; (ii) no uncertainty related to possible changes in the rules on naturalization; and (iii) no uncertainty driven by the return migration decisions of parents. We explain these three types of benefits in more detail. Before the reform, foreigners over 16 years of age, in principle, were eligible for German citizenship if they had spent at least 8 years in Germany since their birth. In practice, children born to immigrant parents had to wait until age 18 in order to become Germans (provided that they met all the residency requirements). ${ }^{\Pi 1}$ Children born in 2000 or after to households where at least 1 parent had been a resident in Germany for 8 years, were entitled to hold dual citizenship at birth and until the age of 23 (Options modell), when they are supposed to choose nationality. This allowance represents a notable exception in the new

\footnotetext{
${ }^{9}$ In the public sector, most careers in the justice and national defense departments are accessible only to German citizens, irrespective of ownership of a passport from another EU member state.

${ }^{10}$ In the private sector, professions such as dentistry, medicine, pharmacy, law, and architecture are restricted to citizens from EU countries.

${ }^{11}$ The legal age for relinquishing former citizenship was 18 , and dual citizenship was not allowed. Parents, in principle, could cancel the citizenship of their children, but only if they had formally resigned their own former citizenship.
} 
institutional framework. Before 2000 dual citizenship was not legally recognized and was rarely tolerated. After 2000 it was explicitly denied by law-with the exception for those below age 23 explained above - and immigrants had to relinquish their original citizenship in order to become German citizens. Relinquishing birth country citizenship might imply some psychological costs for immigrants and is associated with serious limitations in their country of origin. ${ }^{12}$ Individuals with dual nationality also, in principle, have unrestricted access to two labor markets. ${ }^{13}$

Acquiring citizenship at birth neutralizes two sources of uncertainty inherent in the possibility of naturalization later in life. First, it negates any uncertainty about possible changes in the institutional setting. While the norms approved in 1990 and 1993 introduced rule-based criteria for the acquisition of citizenship through naturalization, thus making it easier, a law passed in 1997 set out visa requirements for unaccompanied children from Turkey, the former Yugoslavia, Morocco, and Tunisia, and required existing resident children of parents from these countries to apply for residence permits (Bosswick 2000). Repeated changes in institutional arrangements may have increased immigrants' uncertainty about the timing of citizenship acquisition via naturalization for their children.

Second, and most important, birthright citizenship makes the child's legal status independent of household return migration decisions. As already mentioned, after 1993 children born to immigrant parents and seeking naturalization had to provide evidence of at least eight years of ordinary residence in Germany. ${ }^{14}$ Immigrants to Germany are very likely to return home either permanently or temporarily. Using information on the return migration intentions elicited from the German Socio-Economic Panel, the graph in Figure 1 shows that more than 60 percent of immigrants might return to their home country at some point, and about 45 percent of them are willing to return within 8 years. This evidence is suggestive that a large fraction of immigrants might indeed perceive the possibility to stay in Germany long enough to allow their children to meet the residence requirements as very unlikely. After the reform, the return plans of parents do not affect the legal position of the newborn. ${ }^{15}$

Returns to schooling and health investments are, on average, higher for citizen than noncitizen children. While the Microcensus does not elicit information on wages, we use data on annual gross income, and we find that the magnitude of the correlation between completion of tertiary education and annual gross income is significantly larger for naturalized immigrants than nonnaturalized ones. During the period predating the reform of the nationality law, parents who were not planning to stay in Germany long enough to enable their children to meet the residence requirements might have been less inclined to invest in their children's human capital. Under the

\footnotetext{
${ }^{12}$ Mueller (2006) reports that pre-1996, Turkish regulation deprived individuals of their property rights in Turkey if they abandoned Turkish citizenship.

${ }^{13}$ Mazzolari (2009) exploits the introduction of dual citizenship in five Central and South American countries to show that immigrants from these countries experienced a large increase in the probability of acquiring US citizenship and, as a result, display better labor market outcomes.

${ }^{14}$ According to Section $12 \mathrm{~b}$ of the German Nationality Act, in the presence of interruptions longer than six months, a previous period of residence in Germany might not be counted as contributing toward the duration of residence requirement, and if it were allowed, it would only be up to a period of five years.

${ }^{15}$ There is increasing evidence for Germany on the relationship between return migration intentions and investments in both cultural and economic integration (see Dustmann 1999; Dustmann and Mestres 2011).
} 


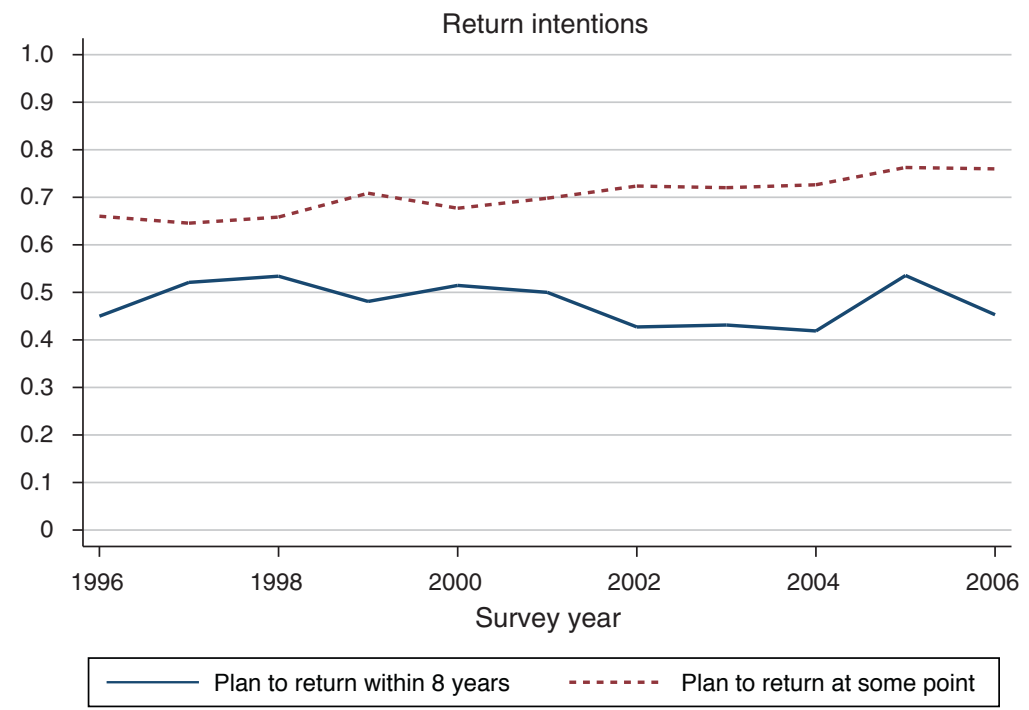

Figure 1. Return Probability

Notes: The dotted line is the proportion of immigrants who claimed they might return to their home country at some point, by survey year. The solid line is the proportion of those who plan to return within eight years with respect to the total number of those who might return, by survey year.

Source: German Socioeconomic Panel (GSOEP)

birthright system, uncertainty about the parental return-migration decision does not affect either childrens' ability to acquire German citizenship or its timing.

\section{Theoretical Framework}

In this section, we discuss two simple theoretical frameworks describing how child legal status can affect both fertility and human capital investment decisions.

The effect of birthright citizenship on immigrants' fertility and child health outcomes can be modeled in a standard "quality-quantity" model (see Becker and Lewis 1973; Becker and Tomes 1976). Parents maximize a utility function $U(n, q, c)$ that depends on $n$; the number of children, $q$; the "quality" per child; and $c$, the consumption rate of all other commodities. Agents face a nonlinear budget constraint: $Y=n p_{n}+n q p+q p_{q}+c p_{c}$. Quality and quantity enter into the budget constraint in a multiplicative way. The cost of an increase in quality is higher the larger the number of children because it will apply to more units. $p_{n}$ is the unitary cost of the number of children that is not dependent on quality, for instance, the opportunity cost of fertility control; $p$ represents the cost of child quality that depends on the total number of children; $p_{q}$ is the unitary cost of child quality that does not depend on quantity; and $p_{c}$ is the price of the consumption good. We can interpret the German nationality law reform and the extension of the citizenship rights as a decrease in the price of child quality, $p_{q}$. A decrease in $p_{q}$, as explained by Becker and Lewis (1973, S283), has a positive direct effect on child quality $q$ and a negative indirect effect on the number of children $n$, due to the increase in the shadow price of quantity $\left(p_{n}+q p\right)$. 
Citizenship rights at birth can also be interpreted as a positive shock to children's endowments (their characteristics) at birth. While a general theoretical model is beyond the scope of this work, we sketch a simple framework that departs from Becker and Lewis (1973) to incorporate the child's endowments, and illustrate the assumptions that translate extension of citizenship rights into lower fertility rates and a higher level of child "quality." Simplifying assumptions are introduced in order to generate easily testable implications.

The average quality of children within a household can be modeled as a standard constant elasticity of substitution (CES) function of the average level of children's endowments at birth, $e$, and parental per child investment in quality, $I$, and assume that parents invest the same amount of resources in each of their children. ${ }^{16}$ The utility function is defined as $U=\gamma \ln c+(1-\gamma)(\ln n+\ln q(e ; I))$, where $c, n$, and $q$ are defined as above. Parents choose $n, I$, and $c$ to maximize their utility function under a budget constraint that includes total expenditure on investment in child quality, total expenditure on the consumption good, and the child costs that depend on quantity but not quality, that is $Y=c p_{c}+n I p_{I}+n p_{n}$, where $p_{c}$ and $p_{n}$ are defined as above and $p_{I}$ represents the price of per child parental investment in child quality. If investment and endowment are complements in the quality production function, ${ }^{17}$ that is, if the elasticity of substitution between a child's initial endowment and parental investment is smaller than one, a positive shock to the child's endowment translates into an increase in the marginal product of investment in quality, and, therefore, in per child level of investment. The subsequent increase in the shadow price of quantity $\left(I p_{I}+p_{n}\right)$ explains the decrease in the optimal number of children.

The two theoretical frameworks presented above are clearly very close and have similar implications. Empirically, it is hard to distinguish between a shock in endowments from a change in the price of child quality. In the rest of the paper we refer generically to the introduction of birthright citizenship as a shock in the return to investment in child human capital.

\section{Empirical Strategy and Data}

\section{A. Empirical Strategy}

We study how the provision that introduced birthright citizenship affects immigrants' fertility. According to the new German nationality law, effective from January 1, 2000, all children born in 2000 or after to non-Germans will be granted German citizenship if at least one parent has been legally residing in the country for at least eight years at the time of the child's birth. In our setting, individuals born to noncitizen parents, at least one of whom has lived in Germany for eight or more years, represent the treatment group. There were no changes in the conditions for children born to parents at least one of whom was a German citizen at the time

\footnotetext{
${ }^{16}$ In Becker and Lewis (1973) and Becker and Tomes (1976), the quality that enters parents' utility function is assumed to be the same for all children.

${ }^{17}$ The assumption of complementarity is supported by findings in the empirical literature (Datar, Kilburn, and Loughran 2010; Gelber and Isen 2013; Aizer and Cuhna 2011) that provide evidence that parental investment reinforces the child's initial endowments.
} 
of the birth, since they automatically received German citizenship. This allows the identification of two comparison groups: first, households where only one (potential) parent is a non-German citizen (from here on referred to as mixed households or Comparison Group I); second, households where none of the (potential) parents is a foreigner (from here on referred to as Comparison Group II). ${ }^{18}$ By comparing the outcomes of the treatment and the two comparison groups before and after the reform, we can identify the effect of the birthright citizenship reform on parental outcomes. Formally, we estimate the following difference-in-differences (DD) model:

$$
\begin{aligned}
Y_{i t}= & \alpha+\beta_{1} C_{i}^{1}+\beta_{2} C_{i}^{2}+\beta_{3} \text { Post }_{t}+\beta_{4} C_{i}^{1} \times \text { Post }_{t}+\beta_{5} C_{i}^{2} \times \text { Post }_{t} \\
& +\beta_{6} C_{i}^{1} \times t+\beta_{7} C_{i}^{2} \times t+\gamma \mathbf{X}_{i t}^{\prime}+\mu_{t}+u_{i t},
\end{aligned}
$$

where $Y_{i t}$ denotes the fertility outcome of the woman in couple $i$ at time $t . C_{i}^{1}$ takes the value 1 if in household $i$ only one parent is a foreign citizen. $C_{i}^{2}$ takes the value 1 if in household $i$ there is no foreign parent. In this specification, immigrant households where neither parent is a German citizen, but at least one has been in Germany for eight or more years, are the reference category. Because of the biological lag between fertility planning decisions and actual outcomes, we treat as postreform period $\left(\right.$ Post $\left._{t}=1\right)$ all the surveys from 2001 onward. Post $t_{t}$ takes the value zero for all surveys before 2001. In the baseline specification, $\mathbf{X}_{i t}$ includes a set of womenspecific characteristics, namely age, dummies for educational attainment, dummies for state of residence, and dummies for being German or a citizen of another European Union member state. In this specification, being a citizen of a non-EU state acts as reference category. $\mu_{t}$ represents a set of year dummies. The baseline specification also includes group-specific linear trends.

The parameters of interest are $\beta_{4}$ and $\beta_{5}$. Since the omitted category in equation (1) is the dummy that denotes the treatment group, $\beta_{4}$ and $\beta_{5}$ measure how the fertility, respectively, of mixed households and households where there is no foreign parent change in comparison to the treatment group after the reform. Standard errors are adjusted for clustering at group/year level in order to account for the possibility of shocks differentially affecting the three groups in a particular year.

Immigrant couples who have been in Germany for less than eight years might also provide a counterfactual for the fertility behavior of couples affected by the citizenship reform. Although they might be more comparable to couples in the treatment group, they might also be partially affected by the reform. Indeed, when deciding the optimal family size, they might take into account that future children will enjoy German citizenship if born once one of the spouses has fulfilled the eight year residency requirement. We discuss these issues more extensively in online Appendix 2, where we also present results obtained using such alternative comparison group.

We next test whether the introduction of birthright citizenship is associated with an improvement in child quality for the cohorts of children affected by the reform. When studying the effect of family size on child quality, previous work has focused on education (Rosenzweig and Zhang 2009; Angrist, Lavy, and Schlosser 2010)

\footnotetext{
${ }^{18}$ For consistency throughout the paper, we will refer to actual or potential parents simply as parents.
} 
or on anthropometric outcomes (Rosenzweig and Zhang 2009). Unfortunately the short time period after the reform does not allow us to test the effect of the reform on educational outcomes. Instead, we study how anthropometric outcomes, as elicited in the Microcensus, and measures of noncognitive and behavioral development, as obtained in the KiGGs data, changed as a result of citizenship being acquired at birth. We do not try to attribute causal interpretations to the relationship between citizenship rights and child quality since the negative effect of the reform on the fertility decisions of immigrants might generate a selection bias. Parents who decide not to try to have a child after 2000, as a result of the reform, may be the same parents who would have invested less in their child's development. . $^{19}$

In order to assess the effect of birthright citizenship on child quality, we exploit the fact that both for anthropometric measures in the Microcensus and noncognitive outcomes in the KiGGs, we have information on child cohorts born before and after the citizenship reform. Nevertheless, being born after 2000 should make a difference only in the quality outcomes of children born to immigrant parents who have been in Germany for eight or more years, but not of children with at most one foreign parent. Formally, we estimate a child-specific version of equation (1) where the dependent variables are child quality outcomes:

$$
\begin{aligned}
Q_{i c t}= & \alpha+\beta_{1} C_{i}^{1}+\beta_{2} C_{i}^{2}+\beta_{3} D_{c}+\beta_{4} D_{c} \times C_{i}^{1} \\
& +\beta_{5} D_{c} \times C_{i}^{2}+\gamma \mathbf{X}_{i t}^{\prime}+\eta_{c}+\mu_{t}+u_{i c t} .
\end{aligned}
$$

$Q_{i c t}$ is the quality health outcome of a child born to a couple $i$ and belonging to cohort $c . C_{i}^{1}$ and $C_{i}^{2}$ are defined as above. $D_{c}$ is a dummy variable equal to 1 if the child was born in 2000 or afterward $(c>=2,000) . \eta_{c}$ and $\mu_{t}$ represent child birth cohort and time fixed effects, respectively. $\mathbf{X}_{i t}$ includes age and gender of the child, and characteristics of the mother in household $i$, namely age, dummies for educational attainment, dummies for state of residence, and dummies for being German citizen or citizen of another European Union member state. ${ }^{20}$ Standard errors are adjusted for clustering at group/cohort level.

In this case, $\beta_{4}\left(\beta_{5}\right)$ larger than zero would be consistent with the "quality-quantity" model. Indeed, we would expect that, compared to children born in households where at least one of the parents is a German citizen, immigrants' children born in 2000 or afterward may have better development outcomes than those born before 2000. This is the case because the reform may have increased the returns to investment in child human capital.

\section{B. Data}

In this study we use three different data sources. The main data are from the German Microcensus, which is a household-based repeated cross-section survey carried out

\footnotetext{
${ }^{19}$ Under certain assumptions, it is possible to provide a lower bound estimate of the effect of the reform on child health driven by increased parental investment. We present the results for this exercise in Appendix B.

${ }^{20}$ In line with the specification in equation (1), being a citizen of a non-EU state acts as an omitted category.
} 
by the German Statistical Office. The survey covers 1 percent of all households in Germany with approximately 370,000 households and 820,000 persons interviewed every year. The primary goal of the Microcensus is to collect information on the structure of the German population and its labor market behavior. The survey started in 1973 and was conducted every two years until 1995. Since 1995 it has been annual.

Information on citizenship status has been collected since 1996. Since this information is crucial for our analysis, we consider only those surveys between 1996 and 2005. The Microcensus provides detailed information on country of birth, citizenship, and the year of arrival of the immigrant, thus, allowing us to define the group of households that is affected by the changes in citizenship rules.

Our sample includes all households where either the head of household's partner or the household head is a woman aged 15-49. For each individual in the household, including children, we know the year of birth. In order to identify the effect of the reform on fertility, we use two different types of information. First, using information on year of birth of each household member, we define a dummy variable that takes the value 1 if in the household there is a child born within the last 12 months. This is our main dependent variable. Since mothers are asked for information on the age structure of all the children living in the household, we can construct measures for the total number of children in different age groups (0-3, 6-9, and 9 years or above), and for the probability of having at least one child in each age group. Information on fertility outcomes was collected in each survey between 1996 and 2005. ${ }^{21}$ Table 1 reports descriptive statistics for the household characteristics of the three groups as elicited in 1999, the year in which the new nationality law was approved. Mothers in the treatment group are, on average, about the same age as those in the group where none of the parents is a foreigner, but they are almost 3 years older than those in the mixed households group (36.4 versus 33.6). Mothers in the treatment group are less educated than those in the two comparison groups. On average, the number of children born to immigrant households (1.56) is higher than the number of children born in mixed (0.86) and German (0.90) households.

The Microcensus also reports information on body weight (in $\mathrm{kg}$ ) and height (in centimeters), but it was collected only in three surveys: 1999, 2003, and 2005. The literature suggests that Body Mass Index (BMI) is a reliable measure of child health for children older than three years. We focus on preschool age children (four and five years) and we use two dependent variables: BMI index, and a dummy variable indicating whether or not the child is obese. Obesity is defined using cutoff points varying by age and gender, recommended by the Childhood Obesity Working Group of the International Obesity Task force.

The second data source is the "German Health Interview and Examination Survey for Children and Adolescents" (henceforth, KiGGs), which is a comprehensive, Germany-wide, representative interview and examination survey for the age group 0-17 years. Between May 2003 and May 2006, 17,641 study participants were enrolled. The sampling consisted of a two-stage procedure. First, 167 primary sample units (PSU) were drawn from an inventory of German communities. Second,

\footnotetext{
${ }^{21}$ Given that we do not have complete fertility histories, we cannot rule out that our results can be explained, at least partially, by the postponement in the timing of births.
} 
Table 1 -SAmple Characteristics in 1999

\begin{tabular}{lccc}
\hline \hline & $\begin{array}{c}\text { Treatment } \\
\text { group } \\
\text { Mean/SD } \\
(1)\end{array}$ & $\begin{array}{c}\text { Comparison } \\
\text { group I } \\
\text { Mean/SD } \\
(2)\end{array}$ & $\begin{array}{c}\text { Comparison } \\
\text { group II } \\
\text { Mean/SD } \\
(3)\end{array}$ \\
\hline Age mother & 36.394 & 33.615 & 36.183 \\
Mother has primary education & $(8.177)$ & $(8.388)$ & $(7.845)$ \\
Mother has secondary education & 0.216 & 0.054 & 0.009 \\
& $(0.412)$ & $(0.225)$ & $(0.092)$ \\
Mother has tertiary education & 0.506 & 0.238 & 0.145 \\
& $(0.500)$ & $(0.426)$ & $(0.352)$ \\
Mother self-employed & 0.244 & 0.678 & 0.826 \\
Mother unemployed & $(0.429)$ & $(0.467)$ & $(0.379)$ \\
Mother is German & 0.017 & 0.044 & 0.042 \\
Mother is EU & $(0.131)$ & $(0.205)$ & $(0.200)$ \\
Observations & 0.071 & 0.089 & 0.073 \\
log HH Income & $(0.257)$ & $(0.285)$ & $(0.261)$ \\
& 0.000 & 0.305 & 1.000 \\
Total number of children & $(0.000)$ & $(0.460)$ & $(0.000)$ \\
& 0.209 & 0.209 & 0.000 \\
& $(0.407)$ & $(0.407)$ & $(0.000)$ \\
& 2.707 & 2.580 & 2.970 \\
& $(1.136)$ & $(1.597)$ & $(1.586)$ \\
& 1.560 & 0.856 & 0.902 \\
& $(1.233)$ & $(1.008)$ & $(1.005)$ \\
& 2,574 & 4,765 & 83,286 \\
\hline
\end{tabular}

Notes: The sample includes households where the woman is in the age group 15-49. The treatment group contains households where at least one partner has lived in Germany for eight or more years. Comparison group I contains households where only parent is a foreigner. Comparison group II contains households with no foreign parent. Summary statistics are computed using the 1999 survey. By construction, the mother is never German in the treatment group and is always German in the second comparison group.

24 addresses for each child birth cohort were randomly selected from local population registries within selected PSUs. The sampling structure and the fact that the survey was spanned over a period of three years allow us to compare the socio-emotional outcomes of children with the same age, but belonging to different cohorts. The data contain objective measures of mental health as well as parent-reported information regarding the socio-emotional development of their children. ${ }^{22}$ Although the data on parental socio-demographic characteristics are not exhaustive, the KiGGs elicits information on nationality, country of birth, and year of immigration of both parents. In order to allow comparisons of the development status of immigrant and nonimmigrant children, the survey oversamples households with migrants status.

The third data source is the German Socioeconomic Panel (GSOEP), which is the longest-running longitudinal survey of private households and persons in the Federal Republic of Germany. It started in 1984 and is conducted every year. It provides representative microdata on individuals and households. Each individual in the relevant household aged over 15 is interviewed. The household head provides

\footnotetext{
${ }^{22}$ For children six years old or older, the KiGGs also collects data on cognitive outcomes. Because of the age bracket, there is no information available for children born after the new citizenship law was introduced.
} 


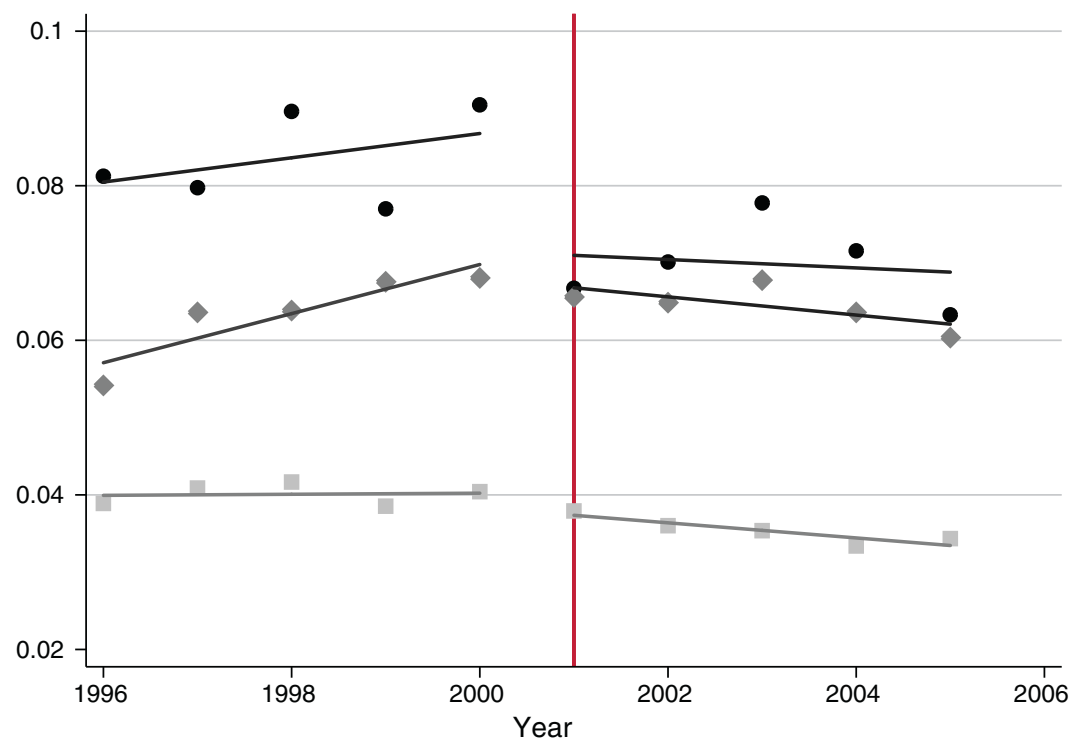

Figure 2. Probability of Having a Child Less Than 12 Months Old

Notes: The graphic plots the fraction of women (aged 15-49) with a child less than 12 months old, by year and group. The circles denote the treatment group; the diamonds the comparison group of households with only one foreign parent; the squares the comparison group where none of the parents is a foreign citizen.

Source: German Microcensus

information on children under the age of 15 . The dataset contains detailed information on country of origin and arrival date of immigrants, and family composition. In each survey foreign born individuals are asked about their citizenship status. On average, 12,000 households and 24,000 individuals have been interviewed every year since 1996. The survey contains quite detailed information on time usage. Both the head of the household and his partner are asked how many hours they spend, on average, every weekday on each activity of work outside the household, child care, household work, care of people in need, educational activities, and shopping. We created a variable for the number of hours of child care in an average working day.

\section{The Effect of Child Legal Status on Fertility}

\section{A. Baseline Results}

We present evidence of the demographic consequences of the German nationality law reform by plotting the evolution over time of the fertility behavior of the three groups defined in the previous section. Figure 2 displays the fraction of women (aged 15-49) with a child born within the previous 12 months, during the time period 1996 to 2005, for each of the three groups. A birth within the previous year is significantly more likely in households in the treatment group (on average 8.5 percent of the households in the treatment group experienced a new birth in 2000 or before) than in households in the two comparison groups; before the reform the average probability of having a child of age zero is about 6.5 percent ( 4 percent) for 
women belonging to households where only one (no) parent is a foreigner citizen. In 2001 , one year after the reform became effective, the fraction of women within the treatment group who gave birth within the previous 12 months drops to 7 percent. The fertility behavior in the two comparison groups does not display, on average, any significant change after the reform. ${ }^{23}$

Table 2 reports the estimates of $\beta_{4}$ and $\beta_{5}$ in equation (1). The two coefficients capture how the fertility of the households belonging to each of the two comparison groups defined above changes with respect to the treatment group, after the reform. The panels report the results for the three dependent variables discussed in the data section. In panel A, the dependent variable is the main variable of interest, the dummy for a child born in the previous 12 months. Column 1 presents the estimates for equation (1) with no control variables and no time dummies. In this case, the size of the two coefficients provides an exact measure of the drop observed in Figure 2. Note that the fact that the two coefficients are positive indicates that the difference between the fertility levels of the treatment and the comparison groups decreased after the reform. We gradually introduce year dummies, group-specific linear trends and the control variables specified in Section IIA. In each specification, we find a significant negative effect of the reform on the fertility outcomes of households where both spouses are immigrants and not German citizens. Column 5 shows the results for the baseline specification, which controls for the woman's age and includes dummies for secondary and tertiary education, for being a German citizen or citizen of an EU member state, for federal state of residence, year, and group specific linear trends. ${ }^{24}$

Irrespective of the specification considered, the effect is sizeable and in line with the one documented in Figure 2. Households in the treatment group are about 1 percentage point less likely to have experienced a new birth within the previous 12 months as a result of the German nationality reform. The effect of the reform corresponds to a 7 percent standard deviation of the dependent variable and slightly above 15 percent of the mean for the treatment group in the prereform period. In panel B of Table 2, we estimate equation (1) using as dependent variable the dummy variable equal to 1 if there is at least one child younger than 3 years of age in the household. The results are consistent with those presented in panel A. The effect of the reform is roughly 14 percent of the mean of the dependent variable within treated households. The conclusions are similar when we look at the number of children younger than three years of age (panel C). Overall, Table 2 presents evidence of a decline in the fertility of immigrants caused by the German nationality law reform. In online Appendix A, we present and discuss results based on the specification that uses immigrants with less than eight years of residence in Germany as alternative control group. While the smaller sizes of the samples considered are likely to

\footnotetext{
${ }^{23}$ In Figure 2, the trends for the three groups before the reform do not look exactly parallel, and this is arguably related to the limited number of observations for the treatment and the first comparison group. In column 4 of Table 2, we present a specification that introduces group linear trends precisely to control for this issue.

${ }^{24}$ The results do not change when we use richer specifications that control for household income, total number of children, and the number of years of residence in Germany. Similarly, the results of the probit specifications are in line with those in panels A and B. Moreover, when we cluster at group-federal state level to control for the possibility of serial correlation, the levels of significance are in line with those for the result presented in Table 2.
} 
TABLE 2-FERTILITY

\begin{tabular}{|c|c|c|c|c|c|}
\hline & (1) & (2) & (3) & (4) & $(5)$ \\
\hline $\begin{array}{l}\text { Panel A. Newborn child } \\
\text { Comparison group I }\end{array}$ & $\begin{array}{c}-0.020 * * * \\
(0.003)\end{array}$ & $\begin{array}{c}-0.020 * * * \\
(0.003)\end{array}$ & $\begin{array}{c}-0.037 * * * \\
(0.002)\end{array}$ & $\begin{array}{c}-0.422 \\
(2.493)\end{array}$ & $\begin{array}{c}-0.612 \\
(2.036)\end{array}$ \\
\hline Comparison group II & $\begin{array}{l}-0.043 * * * \\
(0.002)\end{array}$ & $\begin{array}{l}-0.043^{* * * *} \\
(0.002)\end{array}$ & $\begin{array}{l}-0.077 * * * \\
(0.003)\end{array}$ & $\begin{array}{c}2.052 \\
(1.928)\end{array}$ & $\begin{array}{c}1.762 \\
(1.726)\end{array}$ \\
\hline Comparison group $\mathrm{I} \times$ after & $\begin{array}{l}0.014 * * * \\
(0.004)\end{array}$ & $\begin{array}{l}0.014 * * * \\
(0.004)\end{array}$ & $\begin{array}{l}0.013 * * * \\
(0.003)\end{array}$ & $\begin{array}{c}0.013^{*} \\
(0.007)\end{array}$ & $\begin{array}{c}0.011 * \\
(0.006)\end{array}$ \\
\hline Comparison group II $\times$ after & $\begin{array}{l}0.009 * * \\
(0.003)\end{array}$ & $\begin{array}{l}0.009 * * * \\
(0.003)\end{array}$ & $\begin{array}{l}0.009 * * * \\
(0.003)\end{array}$ & $\begin{array}{l}0.014 * * \\
(0.006)\end{array}$ & $\begin{array}{l}0.014 * * \\
(0.005)\end{array}$ \\
\hline After & $\begin{array}{l}-0.013 * * * \\
(0.003)\end{array}$ & & & & \\
\hline $\begin{array}{l}\text { Time dummies } \\
\text { Group trends } \\
\text { Controls }\end{array}$ & & $\mathrm{X}$ & $\begin{array}{l}X \\
X\end{array}$ & $\begin{array}{l}X \\
X\end{array}$ & $\begin{array}{l}X \\
X \\
X\end{array}$ \\
\hline $\begin{array}{l}\text { Observations } \\
\text { Mean of dep. variable } \\
\text { SD of dep. variable }\end{array}$ & $\begin{array}{c}94,1586 \\
0.040 \\
0.197\end{array}$ & & & & \\
\hline \multicolumn{6}{|c|}{ Panel B. Probability of at least one child younger than three years old } \\
\hline Comparison group I & $\begin{array}{c}-0.061 * * * \\
(0.008)\end{array}$ & $\begin{array}{c}-0.061 * * * \\
(0.007)\end{array}$ & $\begin{array}{c}-0.107 * * * \\
(0.006)\end{array}$ & $\begin{array}{c}-1.445 \\
(5.739)\end{array}$ & $\begin{array}{c}-1.995 \\
(4.543)\end{array}$ \\
\hline Comparison group II & $\begin{array}{l}-0.110 * * * \\
(0.006)\end{array}$ & $\begin{array}{l}-0.110 * * * \\
(0.005)\end{array}$ & $\begin{array}{l}-0.197 * * * \\
(0.007)\end{array}$ & $\begin{array}{c}4.779 \\
(4.641)\end{array}$ & $\begin{array}{c}4.000 \\
(3.750)\end{array}$ \\
\hline Comparison group $\mathrm{I} \times$ after & $\begin{array}{l}0.042 * * * \\
(0.009)\end{array}$ & $\begin{array}{l}0.042 * * * \\
(0.008)\end{array}$ & $\begin{array}{l}0.039 * * * \\
(0.006)\end{array}$ & $\begin{array}{l}0.039 * * \\
(0.019)\end{array}$ & $\begin{array}{l}0.034 * * \\
(0.015)\end{array}$ \\
\hline Comparison group II $\times$ after & $\begin{array}{l}0.014 * * \\
(0.007)\end{array}$ & $\begin{array}{l}0.015^{* *} \\
(0.005)\end{array}$ & $\begin{array}{l}0.015^{* * *} \\
(0.004)\end{array}$ & $\begin{array}{c}0.027 * \\
(0.015)\end{array}$ & $\begin{array}{l}0.026 * * \\
(0.012)\end{array}$ \\
\hline After & $\begin{array}{l}-0.021 * * * \\
(0.007)\end{array}$ & & & & \\
\hline Time dummies & & $X$ & $\mathrm{X}$ & $\mathrm{X}$ & $\mathrm{X}$ \\
\hline Group trends & & & & $\mathrm{X}$ & $\mathrm{X}$ \\
\hline Controls & & & $\mathrm{X}$ & & $\mathrm{X}$ \\
\hline Observations & 94,1586 & & & & \\
\hline Mean of dep.variable & 0.118 & & & & \\
\hline SD of dep. variable & 0.322 & & & & \\
\hline
\end{tabular}

(Continued)

explain the higher standard errors, the point estimates are perfectly in line with those presented here.

As argued in Section IB the economic benefits of German citizenship are substantially larger for non-EU than for EU citizens. If the reduction in fertility documented above is driven by an increase in the returns to children's human capital, we would expect a sharper decrease in fertility among households where neither parent has EU citizenship, since the increase in the returns to human capital of prospective children will be larger for this group. In order to test this hypothesis, we split the treatment group into two subgroups: households where neither parent has EU citizenship and 
TABLE 2-Fertility (Continued)

\begin{tabular}{|c|c|c|c|c|c|}
\hline & $(1)$ & $(2)$ & (3) & (4) & $(5)$ \\
\hline \multicolumn{6}{|c|}{ Panel C. Number of children younger than three years old } \\
\hline Comparison group I & $\begin{array}{c}-0.070 * * * \\
(0.009)\end{array}$ & $\begin{array}{c}-0.070 * * * \\
(0.008)\end{array}$ & $\begin{array}{l}-0.120 * * * \\
(0.007)\end{array}$ & $\begin{array}{c}-3.285 \\
(6.267)\end{array}$ & $\begin{array}{c}-3.878 \\
(4.877)\end{array}$ \\
\hline Comparison group II & $\begin{array}{c}-0.125 * * * \\
(0.006)\end{array}$ & $\begin{array}{c}-0.125^{* * *} \\
(0.005)\end{array}$ & $\begin{array}{c}-0.222 * * * \\
(0.007)\end{array}$ & $\begin{array}{c}3.859 \\
(4.760)\end{array}$ & $\begin{array}{c}2.988 \\
(3.840)\end{array}$ \\
\hline Comparison group I $\times$ after & $\begin{array}{l}0.048 * * * \\
(0.010)\end{array}$ & $\begin{array}{l}0.049 * * * \\
(0.008)\end{array}$ & $\begin{array}{l}0.045^{* * * *} \\
(0.007)\end{array}$ & $\begin{array}{c}0.041 * \\
(0.020)\end{array}$ & $\begin{array}{l}0.035^{* * *} \\
(0.016)\end{array}$ \\
\hline Comparison group II $\times$ after & $\begin{array}{l}0.017 * * \\
(0.007)\end{array}$ & $\begin{array}{l}0.017 * * * \\
(0.006)\end{array}$ & $\begin{array}{l}0.018 * * * \\
(0.004)\end{array}$ & $\begin{array}{c}0.027 * \\
(0.015)\end{array}$ & $\begin{array}{l}0.026 * * \\
(0.012)\end{array}$ \\
\hline After & $\begin{array}{c}-0.025 * * * \\
(0.007)\end{array}$ & & & & \\
\hline Time dummies & & $\mathrm{X}$ & $\mathrm{X}$ & $\mathrm{X}$ & $\mathrm{X}$ \\
\hline Group trends & & & & $\mathrm{X}$ & $\mathrm{X}$ \\
\hline Controls & & & $\mathrm{X}$ & & $\mathrm{X}$ \\
\hline Observations & 94,1586 & & & & \\
\hline Mean of dep. variable & 0.128 & & & & \\
\hline SD of dep. variable & 0.365 & & & & \\
\hline
\end{tabular}

Notes: Robust standard errors clustered at the group-year level in parentheses. The sample includes households where the woman is in the age group 15-49. Comparison groups I and II are defined as in Table 1. The treatment groups are the reference category. Panel A's dependent variable is a dummy equal to 1 if there is a child born within the last 12 months. Panel B's dependent variable is a dummy for whether there is at least one child younger than three years old. Panel C's dependent variable is the number of children younger than three years old. After is a dummy equal to one for all the surveys from 2001 onward. The treatment group is the reference category. Controls include mother's age, mother's education dummies, state of residence dummies, and dummies for whether the mother is German or an EU citizen.

*** Significant at the 1 percent level.

** Significant at the 5 percent level.

* Significant at the 10 percent level.

households where at least one parent has EU citizenship. In the latter case, the newborn child will also be a EU citizen. In columns 1-2 in Table 3, we show that only households where neither parent has EU citizenship experienced a decline in the probability of having a child within the last 12 months, while the effect is basically null for households where at least 1 parent is an EU citizen.

\section{B. Potential Confounders}

We first examine the possibility that our results are capturing the effect of the reform on the composition of the three groups, and in particular the age structure of the households in those groups rather than the effect of the reform on the fertility decisions of immigrants. The 2000 German nationality law may have induced a change in the composition of the treatment/comparison groups by affecting (i) the return migration decision of immigrant parents in the treatment group, (ii) their incentives to become naturalized, and (iii) the likelihood of observing assortative matching in the marriage market.

The incentive to leave Germany should be lower for parents in the treatment group who had a child after 2000. Since this child will have German citizenship 
Table 3-Heterogeneous Effects in Fertility

\begin{tabular}{lcc}
\hline \hline & $\begin{array}{c}\text { Newborn } \\
(1)\end{array}$ & $\begin{array}{c}\text { Newborn } \\
(2)\end{array}$ \\
\hline Comparison group I & $-8.166^{* * *}$ & 1.659 \\
& $(2.624)$ & $(2.555)$ \\
Comparison group II & $-5.807^{* *}$ & $4.001^{*}$ \\
& $(2.367)$ & $(2.295)$ \\
Comparison group I $\times$ after & -0.008 & $0.017^{* *}$ \\
& $(0.009)$ & $(0.007)$ \\
Comparison group II $\times$ after & -0.006 & $0.019^{* * *}$ \\
& $(0.008)$ & $(0.006)$ \\
Sample & & $\mathrm{Not}$ \\
Time dummies & $\mathrm{XU}$ \\
Group trends & $\mathrm{X}$ & $\mathrm{X}$ \\
Controls & $\mathrm{X}$ & $\mathrm{X}$ \\
& & \\
Observations & 921,223 & 935,879 \\
Mean of dep. variable & 0.039 & 0.04 \\
SD of dep. variable & 0.195 & 0.197 \\
\hline
\end{tabular}

\footnotetext{
Notes: Robust standard errors clustered at the group-year level in parentheses. The sample includes households where the woman is in the age group 15-49. Comparison groups I and II are defined as in Table 1. The dependent variable is a dummy equal to 1 if there is a child born within the last 12 months. Controls are the same as those defined in Table 2. Column 1 restricts the treatment group to couples where at least one of the parents is an EU citizen. Column 2 restricts the treatment group to couples where none of the parents is an EU citizen.

*** Significant at the 1 percent level.

** Significant at the 5 percent level.

* Significant at the 10 percent level.
}

and supposedly will enjoy better opportunities in the German and European labor markets, they might decide to stay longer in Germany. While the evidence presented in Figure 1 does not seem to support the hypothesis that the reform changed the return intentions of immigrants living in Germany, a potential reduction in the return migration probability would bias down the size of the drop in fertility. In fact, if that is the case, after the reform, we should observe a higher fraction of immigrant households with a recently born child.

We then investigate whether the results in Table 2 are capturing the effects of changes in naturalization decisions. In the period between 1998 and 2003, the naturalization rate in Germany was around 2 percent. We test whether groups affected differentially by changes in naturalization rules introduced by the 2000 nationality law show a different response in terms of fertility. As discussed in Section IA, on the one hand, the reform introduces less strict residency requirements for naturalization, since it lowers the minimum residency requirement from 15 years to 8 years. On the other hand, it includes the additional requirements described in Section IA. We split the treatment group into two samples: (i) households where at least 1 spouse has been a resident in Germany for more than 15 years at the time of the survey, and (ii) households where at least 1 spouse has been a resident in Germany for between 8 and 15 years at the time of the survey. For households in the first sample, naturalization requirements have become stricter. Before the reform they had an unconditional entitlement to naturalization. Individuals in the second sample are allowed to 
TABle 4-Other Provisions

\begin{tabular}{lcc}
\hline \hline & Newborn & Newborn \\
& $(1)$ & $(2)$ \\
\hline Comparison group I & -3.163 & -1.869 \\
Comparison group II & $(3.538)$ & $(2.243)$ \\
& -0.802 & 0.495 \\
Comparison group I $\times$ after & $(3.353)$ & $(1.950)$ \\
& $0.020^{*}$ & 0.008 \\
Comparison group II $\times$ after & $(0.011)$ & $(0.005)$ \\
& $0.023^{* *}$ & $0.011^{* *}$ \\
Sample & $(0.011)$ & $(0.004)$ \\
Time dummies & & \\
Group trends & $8-15$ years & More 15 years \\
Controls & $\mathrm{X}$ & $\mathrm{X}$ \\
Observations & $\mathrm{X}$ & $\mathrm{X}$ \\
Mean of dep. variable & $\mathrm{X}$ & \\
SD of dep. variable & 921,797 & 935,305 \\
\hline
\end{tabular}

Notes: Robust standard errors clustered at the group-year level in parentheses. The sample includes households where the woman is in the age group 15-49. Comparison groups I and II are defined as in Table 1. The dependent variable is a dummy equal to 1 if there is a child born within the last 12 months. Controls are the same as those defined in Table 2. Column 1 includes households where none of the parents has spent more than 15 years in Germany and where at least 1 has spent between 8 and 15 years in Germany. Column 2 includes households where at least 1 of the parents has spent more than 15 years in Germany.

*** Significant at the 1 percent level.

** Significant at the 5 percent level.

* Significant at the 10 percent level.

apply for naturalization after the reform. Columns 1 and 2 in Table 4 show that there are no statically significant differences in the results for these two groups. ${ }^{25}$

The reform might also have decreased foreigners' incentives to marry someone with German citizenship, thus, leading to increase of the fraction of marriages among noncitizens. This does not seem to be the case since we observe that the percentage of marriages where both spouses are foreign citizens stays constant before and after the reform (around 3 percent).

If our results are an artifact of changes in the sample composition, we may observe changes in the overall age composition of the household. We conduct two tests to rule out this possibility. First, we run the baseline specification including a full set of single year female age dummies, which controls for potential nonlinear effects of female age on fertility. The results are reported in column 2 of Table 5. The coefficients of interest are positive, significantly different from zero, and of very similar size to those in panel A in Table 2. Second, we assess whether there have been changes in the age composition of children not supposed to be affected by the reform. Since we observe fertility for a period of five years after the introduction

\footnotetext{
${ }^{25}$ The size of the coefficients is larger for the sample of immigrant households where at least one parent has lived in Germany for between 8 and 15 years, which is consistent with this group including a higher fraction of women of reproductive age. At the baseline, the fertility rate for this group is about twice as high as that for the group that has been in Germany for more than 15 years.
} 
TABle 5-Fertility: Potential Confounders

\begin{tabular}{lcccccc}
\hline \hline & $\begin{array}{c}\text { Newborn } \\
(1)\end{array}$ & $\begin{array}{c}\text { Newborn } \\
(2)\end{array}$ & $\begin{array}{c}\text { At least one } \\
\text { child 6-9 } \\
(3)\end{array}$ & $\begin{array}{c}\text { Number of } \\
\text { children 6-9 } \\
(4)\end{array}$ & $\begin{array}{c}\text { At least one } \\
\text { child 10-17 } \\
(5)\end{array}$ & $\begin{array}{c}\text { Number of } \\
\text { children 10-17 } \\
(6)\end{array}$ \\
\hline Comparison group I & -6.700 & -0.312 & -2.251 & -7.291 & 8.375 & 15.019 \\
& $(4.377)$ & $(2.421)$ & $(6.042)$ & $(7.048)$ & $(5.348)$ & $(10.472)$ \\
Comparison group II & -1.101 & 0.191 & $12.957^{* *}$ & 10.996 & $16.404 * * *$ & $25.773 * * *$ \\
& $(3.839)$ & $(1.773)$ & $(5.729)$ & $(6.751)$ & $(4.032)$ & $(8.939)$ \\
& & & & & & \\
Comparison group I & -0.006 & & & & & \\
$\quad \times$ after 98 & $(0.005)$ & & & & & \\
Comparison group IIs & -0.005 & & & & & \\
$\quad \times$ after 98 & $(0.005)$ & & & & & \\
Comparison group I & & $0.011^{*}$ & -0.007 & -0.019 & -0.017 & -0.033 \\
$\quad \times$ after & & $(0.006)$ & $(0.016)$ & $(0.018)$ & $(0.015)$ & $(0.028)$ \\
Comparison group II & & $0.013 * *$ & -0.009 & -0.016 & -0.016 & -0.035 \\
$\quad \times$ after & & $(0.005)$ & $(0.015)$ & $(0.017)$ & $(0.011)$ & $(0.022)$ \\
& & & & & & \\
Time dummies & $\mathrm{X}$ & $\mathrm{X}$ & $\mathrm{X}$ & $\mathrm{X}$ & $\mathrm{X}$ & $\mathrm{X}$ \\
Group trends & $\mathrm{X}$ & $\mathrm{X}$ & $\mathrm{X}$ & $\mathrm{X}$ & $\mathrm{X}$ & $\mathrm{X}$ \\
Controls & $\mathrm{X}$ & $\mathrm{X}$ & $\mathrm{X}$ & $\mathrm{X}$ & $\mathrm{X}$ & $\mathrm{X}$ \\
Mother age dummies & & $\mathrm{X}$ & & & & \\
& & & & & & \\
Observations & 479,632 & 941,586 & 941,586 & 941,586 & 941,586 & 941,586 \\
Mean of dep. variable & 0.043 & 0.04 & 0.174 & 0.200 & 0.3 & 0.411 \\
SD of dep. variable & 0.202 & 0.197 & 0.379 & 0.465 & 0.458 & 0.705 \\
\hline
\end{tabular}

Notes: Robust standard errors clustered at the group-year level in parentheses. The sample includes households where the woman is in the age group 15-49. Comparison groups I and II are defined as in Table 1. In columns 1 and 2 , the dependent variable is a dummy equal to 1 if there is a child born within the last 12 months. In column 1 , we restrict the sample to the years prereform, after 98 is a dummy equal to 1 for 1998 onward. In column 2 we control for mother's single year age dummies. In column 3, the dependent variable is a dummy equal to 1 if there is a child aged between 6 and 9 years old. In column 4, the dependent variable is the number of children aged between 6 and 9 years old. In column 5, the dependent variable is a dummy equal to 1 if there is a child aged between 10 and 17 years old. In column 6, the dependent variable is the number of children aged between 10 and 17 years old. Controls are the same as those defined in Table 2.

*** Significant at the 1 percent level.

** Significant at the 5 percent level.

* Significant at the 10 percent level.

of the new regime, we should not observe any change in the probability of having a child aged over five years. For this purpose, we estimate the specification in equation (1) using as dependent variables (i) the probability of having a child aged between 6 and 9 years old, (ii) the number of children between 6 and 9 years, (iii) the probability of having a child aged 10-17, and (iv) the number of children $10-17$. The results in columns 3 to 6 of Table 5 show that $\beta_{4}$ and $\beta_{5}$ are negative and not significantly different from zero. Overall, the results of these tests do not support the hypothesis that the drop in fertility is an artifact of changes in the sample composition.

In order to rule out the possibility that our results might partly reflect differential trends across groups due to unobservable characteristics, we perform a standard robustness test. We consider only prereform surveys, and we assume that the reform was implemented in 1997, thus restricting the sample to the years prereform. We then redefine the postreform variable $\left(\right.$ Post $\left._{t}\right)$ as a dummy that takes the value zero for all surveys before 1998 and estimate the same specification as in equation (1). 
If our results were artificially generated by nonparallel trends in the fertility outcomes of the treatment and comparison groups, we would expect the differences between the level of fertility of the treatment and the two comparison groups to be significantly different after the "placebo" reform. The results of this placebo test are reported in Table 5 column 1 . The coefficients $\beta_{4}$ and $\beta_{5}$ are negative, small, and not significantly different from zero. We also assess the possibility that our results are driven by differences in observable characteristics by using a semiparametric DD model. The results, presented in online Appendix C, support our main findings.

We also disregard the possibility that the reduced immigrants' fertility might be the result of economic shocks or policies more or less contemporaneous with the citizenship reform (e.g., the Hartz Laws and the reform of the parental leave) having a differential effect on treatment and comparison groups. In online Appenidx D, we discuss these alternative explanations in great detail. We find no evidence that women in the treatment group changed their behavior in the labor market after the reform and no evidence of differential changes in the probability that any household member is receiving a welfare benefit.

\section{Child Quality}

In the next two sections we conduct some further tests of the implications of the "quality-quantity" model of human fertility. If the introduction of birthright citizenship represents an increase in the returns to investment in the child's human capital, we can expect an accompanying increase in child quality.

\section{A. Anthropometrics}

The Microcensus collects information on weight and height of all household members, allowing us to construct the BMI for children potentially affected and those not affected by the citizenship reform. Childhood obesity is becoming an increasingly relevant issue, and evidence from a variety of European countries (e.g., Labree et al. 2011) and the United States (Popkin and Udry 1998) suggests that obesity rates are higher among the children of immigrants than among native ones. ${ }^{26}$ Parents can reduce the risk of child obesity by improving the quality of nutritional intake and encouraging physical activity. In our sample, we find that both for children born to German mothers and those born to immigrant mothers, the BMI is negatively correlated with household income and mother's education.

Because of the reduction in fertility documented above, on average, the characteristics of households with a child born in or after 2000 might differ from the characteristics of households whose last child was born in 1999 or before. Therefore, a negative estimate of $\beta_{4}$ and $\beta_{5}$ in equation (2) might capture two effects: (i) higher parental incentives to invest in children granted German nationality at birth, namely the effect of an increase in the returns to human capital of children; (ii) change in the sample composition driven by the reduction in immigrants' fertility, the so called

\footnotetext{
${ }^{26}$ For Germany, Will, Zeeb, and Baune (2005) and Kleiser et al. (2009) find that the probability of being either overweight or obese is dramatically higher for children whose parents have an immigrant status.
} 


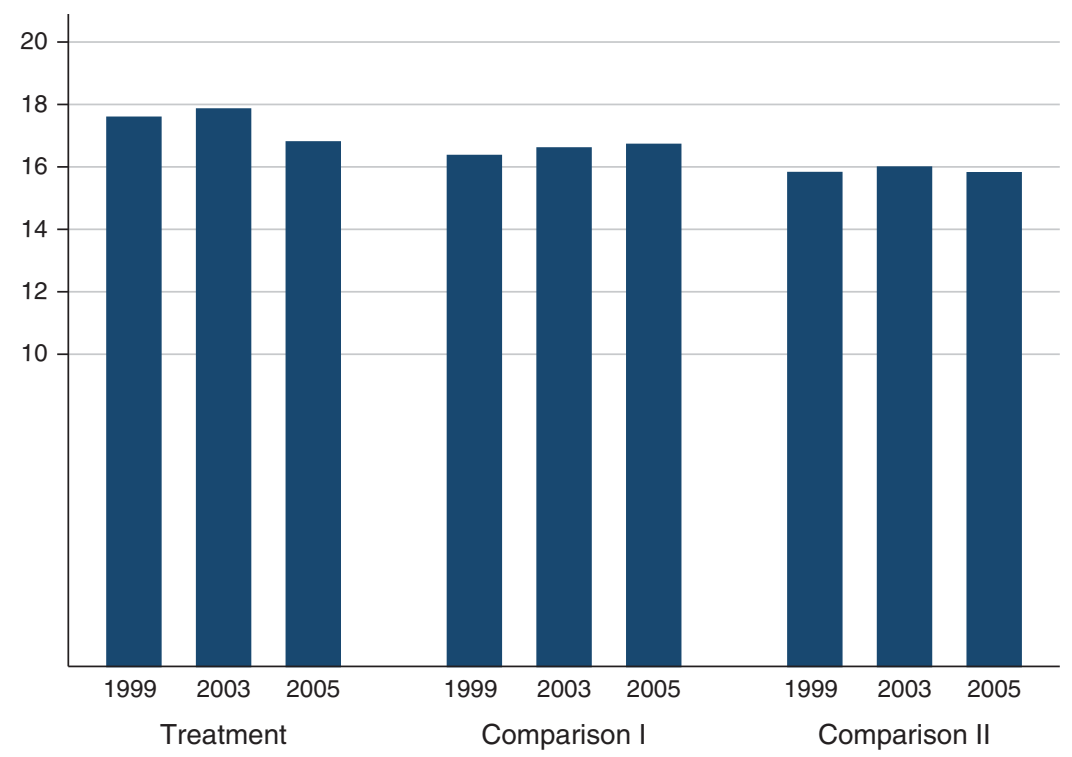

Figure 3. Body Mass Index of Children Age 4-5 by Survey Year

Notes: The graphic plots the computed Body Mass Index for children aged four and five years, by survey year. In the treatment group, only children aged 4-5 in 2005 are affected by the reform. Comparison group I denotes the group where only one parent is a foreign citizen. Comparison group II denotes the group where none of the parents is a foreign citizen.

Source: German Microcensus

"selection effect." At the end of this section we discuss an exercise that provides a lower bound estimate of the former effect. However, we would interpret these results as suggestive, rather than causal evidence.

In Figure 3, we plot the average BMI of children aged four and five in the treatment and the two comparison groups for each survey year in which questions on weight and height were asked, i.e., 1999, 2003 and 2005. Children in the treatment group are citizens only in 2005. Children in the treatment group, on average, display much higher BMI than those in the two control groups in 1999 and 2003, but the differences are significantly smaller in $2005 .{ }^{27}$ Formally, we estimate the specification in equation (2) using BMI and the indicator for being obese as the dependent variables. The results are reported in Table $6{ }^{28}$ The first two columns show the results for BMI, while the last two columns show those for the obesity dummy. The results in columns 1 and 3 are based on the specification without controls, and columns 2 and 4 provide the full specification. For children affected by the reform, we observe a reduction in the BMI of 1.1 and 0.8 points with respect to those born to parents in Comparison groups I and II, respectively. The size of the effect corresponds to

\footnotetext{
${ }^{27}$ A similar picture emerges if instead of BMI we use the probability of being obese, as defined in Section IIB.

${ }^{28}$ In this specification, standard errors are clustered at group/cohort level. Since we only have 18 clusters, we perform the statistical inference drawing critical values from a $t$-distribution with nine degrees of freedom, that is the number of clusters minus the number of cluster-invariant regressors (see Cameron, Gelbach, and Miller 2008).
} 
Table 6-Health Outcomes

\begin{tabular}{|c|c|c|c|c|c|c|}
\hline & $\begin{array}{c}\text { BMI } \\
(1)\end{array}$ & $\begin{array}{c}\text { BMI } \\
(2)\end{array}$ & $\begin{array}{l}\text { Obese } \\
(3)\end{array}$ & $\begin{array}{l}\text { Obese } \\
(4)\end{array}$ & $\begin{array}{c}\mathrm{BMI} \\
(5)\end{array}$ & $\begin{array}{l}\text { Obese } \\
(6)\end{array}$ \\
\hline Comparison group I & $\begin{array}{l}-1.202 * * * \\
(0.263)\end{array}$ & $\begin{array}{l}-0.905^{* * *} \\
(0.244)\end{array}$ & $\begin{array}{c}-0.132 * * * \\
(0.024)\end{array}$ & $\begin{array}{l}-0.092 * * * \\
(0.024)\end{array}$ & $\begin{array}{c}0.256 \\
(0.400)\end{array}$ & $\begin{array}{c}0.027 \\
(0.040)\end{array}$ \\
\hline Comparison group II & $\begin{array}{l}-1.805^{* * * *} \\
(0.262)\end{array}$ & $\begin{array}{l}-1.218 * * * \\
(0.347)\end{array}$ & $\begin{array}{c}-0.172 * * * \\
(0.022)\end{array}$ & $\begin{array}{l}-0.107 * * * \\
(0.028)\end{array}$ & $\begin{array}{c}-0.060 \\
(0.376)\end{array}$ & $\begin{array}{r}-0.007 \\
(0.040)\end{array}$ \\
\hline $\begin{array}{l}\text { Comparison group I } \\
\times \text { born after } 2000\end{array}$ & $\begin{array}{l}1.123 * * * \\
(0.274)\end{array}$ & $\begin{array}{l}1.169 * * * \\
(0.213)\end{array}$ & $\begin{array}{l}0.120^{* * * *} \\
(0.032)\end{array}$ & $\begin{array}{l}0.118^{* * * *} \\
(0.032)\end{array}$ & & \\
\hline $\begin{array}{c}\text { Comparison group II } \\
\times \text { born after } 2000\end{array}$ & $\begin{array}{l}0.816^{* * * *} \\
(0.265)\end{array}$ & $\begin{array}{l}0.883^{* * * *} \\
(0.208)\end{array}$ & $\begin{array}{l}0.074 * * * \\
(0.030)\end{array}$ & $\begin{array}{l}0.079 * * * \\
(0.032)\end{array}$ & & \\
\hline $\begin{array}{r}\text { Comparison group I } \\
\times \text { born after } 1997\end{array}$ & & & & & $\begin{array}{c}-0.444 \\
(0.395)\end{array}$ & $\begin{array}{r}-0.017 \\
(0.041)\end{array}$ \\
\hline $\begin{array}{l}\text { Comparison group II } \\
\times \text { born after } 1997\end{array}$ & & & & & $\begin{array}{c}-0.222 \\
(0.347)\end{array}$ & $\begin{array}{c}0.007 \\
(0.033)\end{array}$ \\
\hline $\begin{array}{l}\text { Sample } \\
\text { Controls }\end{array}$ & Age 4-5 & $\begin{array}{c}\text { Age 4-5 } \\
\text { X }\end{array}$ & Age 4-5 & $\begin{array}{c}\text { Age 4-5 } \\
\text { X }\end{array}$ & Age 6-8 & $\begin{array}{c}\text { Age } 6-8 \\
X\end{array}$ \\
\hline Observations & 10,991 & 10,800 & 10,991 & 10,800 & 17,095 & 17,095 \\
\hline Mean of dep. variable & 15.972 & 15.967 & 15.972 & 15.967 & 16.369 & 0.097 \\
\hline SD of dep. variable & 3.210 & 3.202 & 3.210 & 3.202 & 2.983 & 0.296 \\
\hline
\end{tabular}

Notes: Robust standard errors clustered at the group-cohort level in parentheses. Statistical significance based on the critical value from a $t$-distribution with nine degrees of freedom. Comparison groups I and II are defined as in Table 1. Born after 2000 is a dummy equal to one if the child was born in 2000 or afterward. In columns $1-4$, the sample is composed of children aged four and five years old. In columns 5 and 6 , the sample is composed of children aged 6-8 years old. BMI is constructed using Microcensus data on weight and height. Obese is a dummy variable equal to one if the child is classified as obese, according to the cutoff points varying by age and gender recommended by the Childhood Obesity Working Group of the International Obesity Task force. In columns 1-4, the sample is composed of children aged 4 and 5 years old. In columns 5 and 6 , the sample is composed of children aged 6-8 years old. Controls include child's age and gender, child birth cohort dummies, year dummies, mother's age, mother's education dummies, state of residence dummies, and dummies for whether the mother is German or an EU citizen.

*** Significant at the 1 percent level.

** Significant at the 5 percent level.

* Significant at the 10 percent level.

approximately one-fifth of 1 standard deviation of the BMI observed in the treatment group for cohorts born before the reform. Results for the specifications that use the indicator for being obese as the dependent variable support the conclusion that there has been a substantial improvement in the anthropometric outcomes of immigrant children born after 2000 .

Immigrant children aged over five in 2005 were not granted citizenship at birth. Therefore, if the reduction in BMI is driven by the reform, we would not expect the BMI of children aged 6-8 in 2005 to be systematically different from the BMI of children aged 6-8 in 2003 and 1999. The results of this falsification exercise are presented in Table 6 columns 5 and 6 . Both for the BMI and the obesity dummy, the coefficients are small and statistically not significant.

The obesity gap between the preschool age children of noncitizens and citizens drops significantly for children born in 2000 or immediately afterward compared to those born immediately before 2000. However, our results might be reflecting, at least partially, changes in the composition of the sample of children belonging to the treatment group and born after 2000. This would apply if parents who decided 
not to have a child after 2000 are the same parents who would have invested less in their child's human capital. We provide an estimate of the effect of citizenship rights on health outcomes, which is bounded in order to take account of this possible source of bias. Our bounding procedure is in the spirit of Card, Dobkin, and Maestas (2009) and Lee (2009) and is presented in online Appendix B, we obtain that the higher incentives to invest in the health of citizen children have led to a reduction in childhood obesity of at least 3 percentage points. Under the current German system, there are no differences in the provision of both child care and essential health services—including prenatal and postnatal ones-based on individual citizenship status. Therefore, we interpret the reduction in childhood obesity as evidence of increased parental attention rather than of a change in the access to health care.

\section{B. Social and Behavioral Development}

In this section, we study whether immigrant children who acquired German citizenship at birth displayed changes in measures of child development, other than the anthropometric ones. The KiGGS does collect, among other measures, measures of children's noncognitive skills and well being. The sample size is small compared to the Microcensus one. The initial sample consists of 2,663 children aged between 3 and 5, born between 1997 and 2002.29

We estimate the equation (2) using two different sets of measures. ${ }^{30}$ First, in order to measure the effect on children's noncognitive skills, we use answers to the Strength and Difficulties Questionnaire (SDQ). ${ }^{31}$ Parents were asked 25 questions that measure children's difficulties in four different domains and their prosocial behavior. The four different domains for difficulties refer to: (i) emotional symptoms; (ii) conduct problems; (iii) hyperactivity; and (iv) peer relationship problems. The SDQ also reports a total difficulties score, that is given by the sum of the first four scores. The prosocial behavior score is meant to capture the degree of helping, cooperation, and altruism. In order to allow for a homogenous interpretation across all six scores, we invert the prosocial behavior score and call it antisocial behavior score. Each score ranges from 0 to 10, with 0 indicating no problems and 10 indicating severe problems in the respective dimension.

Second, we use parents' answers to a battery of questions (24 items) belonging to the so-called KINDL-R test developed by Ravens-Sieberer and Bullinger (1998), and designed to assess a child's well-being. The different dimensions of the test cover: (i) physical well-being; (ii) emotional well-being; (iii) self-worth; (iv) well-being related to the family; (v) well-being related to friends; and (vi) well-being related to school. Moreover, the KINDL-R test allows for construction of an aggregated index signifying a child's total quality of life. For this second

\footnotetext{
${ }^{29}$ For children outside the age range three-five, it is not possible to compare children born before and after the German nationality reform.

${ }^{30}$ Unlike the Microcensus, the KiGGs does not provide comparable information for education acquired outside Germany and does contain information on the federal state of residency. For this reason, the specifications based on the KiGGs data do not include controls for mother's education and state dummies.

${ }^{31}$ The SDQ is a behavioral screening questionnaire that was developed by Goodman (1997) and has been validated and translated in different languages. Unlike other behavioral tests, it has been shown to be reliable in different populations.
} 
TABLE 7-Behavioral Issues

\begin{tabular}{|c|c|c|c|c|c|c|}
\hline & $\begin{array}{c}\text { Emotional } \\
\text { issues } \\
(1)\end{array}$ & $\begin{array}{l}\text { Verbal } \\
\text { issues } \\
(2)\end{array}$ & $\begin{array}{c}\text { Hyperactive } \\
\text { issues } \\
(3)\end{array}$ & $\begin{array}{l}\text { Peer } \\
\text { issues } \\
(4)\end{array}$ & $\begin{array}{c}\text { Antisocial } \\
\text { behavior } \\
\text { score } \\
(5)\end{array}$ & $\begin{array}{l}\text { Total } \\
\text { difficulties } \\
\text { score } \\
(6)\end{array}$ \\
\hline Comparison group I & $\begin{array}{c}0.086 \\
(0.124)\end{array}$ & $\begin{array}{r}-0.040 \\
(0.130)\end{array}$ & $\begin{array}{c}-0.189 * \\
(0.094)\end{array}$ & $\begin{array}{l}-0.689 * * \\
(0.246)\end{array}$ & $\begin{array}{c}0.218 \\
(0.144)\end{array}$ & $\begin{array}{l}-0.299 * * \\
(0.106)\end{array}$ \\
\hline Comparison group II & $\begin{array}{c}0.103 \\
(0.158)\end{array}$ & $\begin{array}{c}-0.287 * \\
(0.143)\end{array}$ & $\begin{array}{c}-0.268 * \\
(0.129)\end{array}$ & $\begin{array}{l}-0.976 * * * \\
(0.220)\end{array}$ & $\begin{array}{r}-0.136 \\
(0.212)\end{array}$ & $\begin{array}{l}-0.504 * * * \\
(0.125)\end{array}$ \\
\hline $\begin{array}{l}\text { Comparison group I } \\
\times \text { born after } 2000\end{array}$ & $\begin{array}{c}0.211 \\
(0.155)\end{array}$ & $\begin{array}{r}-0.060 \\
(0.153)\end{array}$ & $\begin{array}{c}0.116 \\
(0.088)\end{array}$ & $\begin{array}{c}0.513^{*} \\
(0.272)\end{array}$ & $\begin{array}{r}-0.288^{*} \\
(0.129)\end{array}$ & $\begin{array}{l}0.292^{*} \\
(0.131)\end{array}$ \\
\hline $\begin{array}{c}\text { Comparison group II } \\
\times \text { born after } 2000\end{array}$ & $\begin{array}{c}0.065 \\
(0.111)\end{array}$ & $\begin{array}{c}0.142 \\
(0.087)\end{array}$ & $\begin{array}{c}0.122 \\
(0.071)\end{array}$ & $\begin{array}{c}0.384 * \\
(0.188)\end{array}$ & $\begin{array}{c}0.066 \\
(0.097)\end{array}$ & $\begin{array}{l}0.264^{* * * *} \\
(0.051)\end{array}$ \\
\hline Sample & \multicolumn{6}{|c|}{ Age $3-5$} \\
\hline Controls & $\mathrm{X}$ & $\mathrm{X}$ & $\mathrm{X}$ & $\mathrm{X}$ & $\mathrm{X}$ & $\mathrm{X}$ \\
\hline Observations & 2,617 & 2,617 & 2,618 & 2,614 & 2,622 & 2,614 \\
\hline
\end{tabular}

Notes: Robust standard errors clustered at the group-cohort level in parentheses. Statistical significance based on the critical value from a $t$-distribution with nine degrees of freedom. Comparison groups I and II are defined as in Table 1. Born after 2000 is a dummy equal to one if the child was born in 2000 or afterward. The dependent variables are standardized with respect to mean and the standard deviation for children born before 2000 to German parents. The table reports the results for the Strength and Difficulties Questionnaire (SDQ) and the the dependent variables are defined in such a way that lower values signify a better performance of the child. The Antisocial Behavior Score presented in column 5 is created inverting the original prosocial behavior score. The Total Difficulties Score presented in column 6 is the sum of the dependent variables from columns 1 to 4 . Controls include child's age and gender, child birth cohort dummies, year dummies, mother's age, mother's education dummies, state of residence dummies, and dummies for whether the mother is German or an EU citizen.

*** Significant at the 1 percent level.

** Significant at the 5 percent level.

* Significant at the 10 percent level.

set of outcomes higher values denote higher child well-being. Each score is defined between 0 and 100. For interpretational convenience, we standardize all measures for children's noncognitive skills and well-being with respect to mean and the standard deviation of children born before 2000 in households where neither parent is a foreign citizen. ${ }^{32}$

Table 7 presents the results for the SDQ. In at least three of the five domains measured by the SDQ, immigrants' children present a higher number of issues compared to those children with at least one German parent. Differences are particularly striking in the indicator that captures peer-related issues, with children with no foreign parent displaying a number of issues that is almost 1 standard deviation lower than children with no German parent. For those born in 2000 or afterward, the gap between children born to German and non-German parents shrinks significantly. Column 6 provides a measure of the overall effect of the citizenship reform on behavioral and social issues: for children born in 2000 or afterward, the difference in the total difficulties score between immigrants' children and children with only one foreign parent shrinks by 0.29 standard deviations. Similarly, the difference between

\footnotetext{
clusters.

${ }^{32}$ Also in this case, the statistical inference is based on a t-distribution that accounts for the small number of
} 
TABLE 8-Well-Being

\begin{tabular}{|c|c|c|c|c|c|c|c|}
\hline & $\begin{array}{l}\text { Well-being: } \\
\text { Body } \\
(1)\end{array}$ & $\begin{array}{l}\text { Well-being: } \\
\text { Soul } \\
(2)\end{array}$ & $\begin{array}{c}\text { Well-being: } \\
\text { Self } \\
(3)\end{array}$ & $\begin{array}{l}\text { Well-being: } \\
\text { Family } \\
(4)\end{array}$ & $\begin{array}{l}\text { Well-being: } \\
\text { Friends } \\
(5)\end{array}$ & $\begin{array}{l}\text { Well-being: } \\
\text { School } \\
(6)\end{array}$ & $\begin{array}{c}\text { Total } \\
\text { well-being } \\
(7)\end{array}$ \\
\hline Comparison group I & $\begin{array}{c}0.141 \\
(0.179)\end{array}$ & $\begin{array}{c}0.041 \\
(0.188)\end{array}$ & $\begin{array}{r}-0.129 \\
(0.209)\end{array}$ & $\begin{array}{c}-0.164 \\
(0.117)\end{array}$ & $\begin{array}{c}0.231 \\
(0.187)\end{array}$ & $\begin{array}{l}0.528 * * * \\
(0.105)\end{array}$ & $\begin{array}{c}0.152 \\
(0.128)\end{array}$ \\
\hline Comparison group II & $\begin{array}{c}0.304 \\
(0.205)\end{array}$ & $\begin{array}{c}0.049 \\
(0.184)\end{array}$ & $\begin{array}{c}0.037 \\
(0.341)\end{array}$ & $\begin{array}{c}-0.153 \\
(0.149)\end{array}$ & $\begin{array}{c}0.199 \\
(0.155)\end{array}$ & $\begin{array}{l}0.424 * * * \\
(0.145)\end{array}$ & $\begin{array}{c}0.266 \\
(0.163)\end{array}$ \\
\hline $\begin{array}{l}\text { Comparison group I } \\
\times \text { born after } 2000\end{array}$ & $\begin{array}{r}-0.183 \\
(0.188)\end{array}$ & $\begin{array}{r}-0.283 \\
(0.203)\end{array}$ & $\begin{array}{c}0.055 \\
(0.166)\end{array}$ & $\begin{array}{c}0.043 \\
(0.151)\end{array}$ & $\begin{array}{r}-0.247 \\
(0.223)\end{array}$ & $\begin{array}{l}-0.496 * * * \\
(0.131)\end{array}$ & $\begin{array}{c}-0.231 \\
(0.150)\end{array}$ \\
\hline $\begin{array}{c}\text { Comparison group II } \\
\times \text { born after } 2000\end{array}$ & $\begin{array}{r}-0.253 \\
(0.162)\end{array}$ & $\begin{array}{r}-0.231 \\
(0.192)\end{array}$ & $\begin{array}{c}-0.013 \\
(0.157)\end{array}$ & $\begin{array}{c}0.050 \\
(0.096)\end{array}$ & $\begin{array}{r}-0.162 \\
(0.134)\end{array}$ & $\begin{array}{l}-0.328 * * * \\
(0.092)\end{array}$ & $\begin{array}{l}-0.267 * * * \\
(0.069)\end{array}$ \\
\hline $\begin{array}{l}\text { Sample } \\
\text { Controls }\end{array}$ & $\mathrm{X}$ & $\mathrm{X}$ & $X$ & $\begin{array}{c}\text { Age } 3-5 \\
X\end{array}$ & $\mathrm{X}$ & $\mathrm{X}$ & $\mathrm{X}$ \\
\hline Observations & 2,567 & 2,577 & 2,567 & 2,598 & 2,589 & 2,299 & 2,585 \\
\hline
\end{tabular}

Notes: Robust standard errors clustered at the group-cohort level in parentheses. Statistical significance based on the critical value from a $t$-distribution with nine degrees of freedom. Comparison groups I and II are defined as in Table 1. Born after 2000 is a dummy equal to one if the child was born in 2000 or afterward. The dependent variables are standardized with respect to mean and the standard deviation for children born before 2000 to German parents. The table reports the results for the KINDL-R test and higher values denote a higher child well-being. Controls include child's age and gender, child birth cohort dummies, year dummies, mother's age, mother's education dummies, state of residence dummies, and dummies for whether the mother is German or an EU citizen.

*** Significant at the 1 percent level.

** Significant at the 5 percent level.

* Significant at the 10 percent level.

immigrants' children and children with no foreign parent shrinks by 0.26 standard deviations. Both effects are statistically significant.

A similar picture emerges from the measures of well-being in Table 8. Among children born before 2000, immigrants' children display, on average, lower levels of well-being compared to children with at least one German parent. Not surprisingly, the difference is particularly large and statistically significant for the variable that measures well-being in school. Nevertheless, for those born after 2000, the gaps shrink significantly. ${ }^{33}$ Column 7 displays the results for the variable that aggregates the 6 domains of child well-being: overall the reform leads to an increase in the well-being of children born to non-German parents by 0.23 standard deviations compared to children with only one foreign parent, and 0.26 standard deviations compared to those with no foreign parent.

Overall, the results presented in this section suggest that the citizenship reform led to an improvement of the socio-emotional outcomes of children in the treatment group. Nevertheless there are two important caveats in their interpretation. First, in line with the obesity results, the effects might be explained, at least partially, by the selection issue driven by the reduced fertility. Second, since the outcome measures

\footnotetext{
${ }^{33}$ Both for noncognitive skills and well-being outcomes, we are considering multiple outcomes. We test whether the interaction terms for the multiple domains are jointly zero for both comparison groups. For both set of outcomes the joint F-test strongly rejects the null hypothesis for the two groups.
} 
are parents-reported, we can not rule out the hypothesis that the reform affected parents' perceptions.

\section{Channel: Time with the Mother}

Previous studies report evidence of a positive relationship between maternal employment and childhood obesity (see Anderson, Butcher, and Levine 2003; von Hinke Kessler Scholder 2008). Fertig, Glomm, and Tchernis (2009) provide evidence for the US suggesting that the association between maternal employment and childhood obesity might be caused by working mothers devoting less time to child supervision and meal preparation. ${ }^{34}$ Although early work (Ruhm 2004) finds a negative correlation between maternal employment and child cognitive development, the evidence on the short-run effects of female labor force participation on noncognitive outcomes is not conclusive (see Almond and Currie 2011 for a recent review).

In this section, we test whether the time allocation of immigrant mothers changed in response to the presence of at least one German citizen among their offspring. In particular, we study whether the number of hours dedicated to childcare, elicited from the GSOEP, changed in response to the introduction of birthright citizenship. We do not have child specific measures of parental investment, but only a measure of the total number of hours of child care spent by mothers and fathers within an average week day. In the absence of full reallocation of childcare from noncitizen to citizen children, however, mothers in the treatment group whose youngest child was born in 2000 or afterward should spend more time childrearing than those whose youngest child was born before 2000 . Whether the youngest child was born before or after 2000 should not matter for those households where at least one parent is a German citizen. We restrict our sample to households where the youngest child was aged three years old or less.

We use a difference-in-differences specification, and we compare the time allocation of parents whose youngest child was born in or after 2000 with the time allocation of parents whose youngest child was born before 2000 in the treatment group and in the comparison groups. Estimates are reported in Table 9. The first two columns, respectively, without and with controls, show that mothers in the treatment group spend around one and a half hours more per day engaged in childcare if their youngest child is a citizen. The size of the effect corresponds to approximately one-third of one standard deviation of the dependent variable computed for the cohorts in the treatment group born before the reform. 35

While the coefficients of fathers are not negligible in size, they are not significant. We perform a falsification exercise where we restrict the sample to the parents with a youngest child born before 2000, and we compare mothers whose youngest child was born after or in 1997 with those whose youngest child was born before 1997.

\footnotetext{
${ }^{34}$ Cawley and Liu (2007), based on the American Time Use Survey, find that working women spend significantly less time grocery shopping, cooking, eating, and playing with their children, and are more likely to buy prepared foods. Their results suggest also that decreased maternal time for childcare is only partly offset by partners.

${ }^{35}$ Results are robust to including dummies for the number of children aged between 0 and 6 .
} 
TABLE 9-PARENTAL INVESTMENT

\begin{tabular}{|c|c|c|c|c|c|}
\hline & \multicolumn{2}{|c|}{$\begin{array}{l}\text { Women } \\
\text { childcare }\end{array}$} & \multirow{2}{*}{$\begin{array}{c}\text { Men } \\
\text { childcare } \\
(3)\end{array}$} & \multirow{2}{*}{$\begin{array}{l}\text { Placebo } \\
\text { (4) }\end{array}$} & \multirow{2}{*}{$\begin{array}{c}\text { Women } \\
\text { working hours } \\
(5)\end{array}$} \\
\hline & (1) & (2) & & & \\
\hline Comparison group I & $\begin{array}{l}2.577 * * * \\
(0.584)\end{array}$ & $\begin{array}{l}2.001 * * * \\
(0.599)\end{array}$ & $\begin{array}{c}0.566^{*} \\
(0.287)\end{array}$ & $\begin{array}{l}1.255 \\
(1.199)\end{array}$ & $\begin{array}{l}-2.083 * * * \\
(0.516)\end{array}$ \\
\hline Comparison group II & $\begin{array}{l}2.262 * * * \\
(0.535)\end{array}$ & $\begin{array}{l}1.622 * * * \\
(0.564)\end{array}$ & $\begin{array}{c}0.321 \\
(0.193)\end{array}$ & $\begin{array}{l}0.72 \\
(1.153)\end{array}$ & $\begin{array}{c}-1.498 * * \\
(0.552)\end{array}$ \\
\hline $\begin{array}{r}\text { Comparison group I } \\
\times \text { born after } 2000\end{array}$ & $\begin{array}{l}-1.785^{* *} \\
(0.775)\end{array}$ & $\begin{array}{c}-1.517 * \\
(0.809)\end{array}$ & $\begin{array}{r}-0.512 \\
(0.323)\end{array}$ & & $\begin{array}{l}1.921 * * \\
(0.723)\end{array}$ \\
\hline $\begin{array}{c}\text { Comparison group II } \\
\times \text { born after } 2000\end{array}$ & $\begin{array}{l}-1.791 * * * \\
(0.594)\end{array}$ & $\begin{array}{l}-1.506^{* *} \\
(0.600)\end{array}$ & $\begin{array}{r}-0.208 \\
(0.213)\end{array}$ & & $\begin{array}{l}2.614 * * * \\
(0.574)\end{array}$ \\
\hline $\begin{array}{r}\text { Comparison group I } \\
\times \text { born after } 1997\end{array}$ & & & & $\begin{array}{c}0.506 \\
(1.364)\end{array}$ & \\
\hline $\begin{array}{c}\text { Comparison group II } \\
\times \text { born after } 1997\end{array}$ & & & & $\begin{array}{c}0.553 \\
(1.224)\end{array}$ & \\
\hline Born after 2000 & $\begin{array}{l}1.295 * * \\
(0.533)\end{array}$ & & & & \\
\hline Youngest child age dummies & & $\mathrm{X}$ & $\mathrm{X}$ & $\mathrm{X}$ & $\mathrm{X}$ \\
\hline Time dummies & & $X$ & $\mathrm{X}$ & $\mathrm{X}$ & $\mathrm{X}$ \\
\hline Controls & & $\mathrm{X}$ & $\mathrm{X}$ & $X$ & $\mathrm{X}$ \\
\hline Observations & 5,488 & 5,441 & 4,744 & 2,284 & 118,521 \\
\hline Mean of dep. variable & 9.729 & 9.738 & 1.995 & 9.866 & 14.594 \\
\hline SD of dep. variable & 6.234 & 6.242 & 2.232 & 6.07 & 17.265 \\
\hline
\end{tabular}

Notes: Robust standard errors clustered at the group-cohort level in parentheses. Comparison groups I and II are defined as in Table 1 . Born after 2000 is a dummy equal to one if the child was born in 2000 or afterward. In columns 1 to 4, the data source is the GSOEP. In columns 1, 2, and 4, the dependent variable is the mother's total number of hours of child care on an average week day. In column 3, the dependent variable is the father's total number of hours of child care on an average week day, where the youngest child was aged three years old or less. Controls include mother's age, mother's education dummies, state of residence dummies, and dummies for whether the mother is German or an EU citizen. Column 3 also includes father's age as a control. In column 4 we restrict the sample to parents with a youngest child born before 2000, Born after 1997 is a dummy equal to one if the youngest child was born from 1997 onward. The results in column 5 are based on the Microcensus. The dependent variable is the number of weekly working hours.

*** Significant at the 1 percent level.

** Significant at the 5 percent level.

* Significant at the 10 percent level.

Given that neither children born before nor after, nor in 1997, were affected by the reform, we do not expect to find any effect when comparing the time allocation of their mothers. The coefficients reported in column 4 are much smaller and not statistically significant.

Since we document the existence of a substantial increase in the number of hours of child care spent by mothers in response to the introduction of birthright citizenship, we then check whether we observe a corresponding reduction in the observed number of working hours. While the Microcensus does not provide any information on the hours of child care spent by the respondent, it does include the self-reported number of hours worked by the respondent in the week before the interview. We then adopt the same empirical strategy used in column 1 of Table 9 and study whether treatment mothers whose youngest child was born in 2000 or afterward indeed spend less time in the workplace than those whose youngest child 
was born before 2000. ${ }^{36}$ Results are reported in column 5 of Table 9 and seem to confirm our prediction. The increase in the hours of child care spent by mothers whose youngest child was affected by the reform is accompanied by a (smaller) reduction in the their working hours. ${ }^{37}$

\section{Discussion}

Sections III and IV present a fairly large set of results that appear to be consistent with our admittedly stylized version of a "quality-quantity" framework. In this section, we discuss more extensively the potential mechanisms through which the "quality-quantity" model might operate in our context, and we also consider alternative mechanisms through which immigrants might adjust their fertility behavior as a result of the citizenship law we study. In our opinion, there are at least three margins along which immigrants might change their behavior in order to improve their children's outcomes: (i) increase in the time devoted to child care, (ii) change in the consumption/saving patterns over the life cycle, and (iii) increased cultural assimilation. In Section IVC, we provide evidence that supports the first explanation.

The improvement in child "quality" might, however, also be driven by different household consumption decisions. In response to the change in child legal status, immigrant parents might increase their expenditure in child-related items. Alternatively, parents might allow their children to attend a better school by moving to a better (and potentially less segregated) neighborhood. This information is, however, not present in the Microcensus (or not available to us, as for instance information about the neighborhood of residence of the household), therefore we leave the investigation of such a mechanism to future research.

We also suggest the possibility that a cultural channel is at work. Immigrants might perceive that in order for their children to take better advantage of the new opportunities they need to be more integrated with the local culture, and, as a consequence, might decide to assimilate more and converge to natives' pattern in terms of fertility behavior and investment in their children. In our analysis, we are not able to separate the "quality-quantity" from a pure cultural channel. However, we are skeptical that the latter can fully explain our findings. Cultural norms are very persistent over time, and we find unlikely that the citizenship reform we study can lead to the rapid change in immigrants' cultural assimilation needed to explain the fertility drop documented in Figure 2.

Alternative mechanisms could be based on an hypothetical relationship between the time that parents plan to spend in the host country and citizenship rights of children. As a result of the reform, parents may decide to stay longer in Germany and this might increase parents' incentives to invest in their own human capital. If the increase in human capital led to an increase in female labor supply, this might explain the reduction in fertility. Neither the evidence on return intentions presented

\footnotetext{
${ }^{36}$ The dependent variable, the number of working hours in the week before the interview, takes value zero if the respondent has reported to not be employed in that week.

${ }^{37}$ The size of the coefficients in columns 1 and 5 are not immediately comparable as in column 1 the dependent variable is hours of child care within an average week day and in column 5 hours of work in the previous week.
} 
in Figure 1 nor the evidence on female labor supply in online Appendix D support this hypothesis. Nevertheless, a potential change in immigrants' expected stay in Germany is not orthogonal to the two channels previously highlighted. In fact, parents might have changed their planned horizon in Germany either because of a stronger assimilation with German culture or because they intend to invest more in their children in order to allow them to take advantage of the economic opportunities related to German citizenship.

Immigrant parents might have increased their efforts to find a job, learn the German language, and minimize their chances of unemployment and welfare dependence in order to be eligible for naturalization under the new rules introduced by the 2000 reform. The evidence presented in Table 4 does not provide support to the hypothesis that the fertility drop is driven by a change in the naturalization rules for adults. We also find no evidence that the probability of receiving a social program benefit changes after 2000. Also, in this case, an increased willingness to become a German citizen would not be incompatible with the "quality-quantity" model, as parents might increase their efforts to become German citizens if they perceive that their legal status can facilitate their children's economic and cultural assimilation.

\section{Conclusion}

The results of the investigation in this paper suggest a negative and significant effect of birthright citizenship on immigrants' fertility. We can provide evidence that changes in child quality are consistent with the predictions of the "quality-quantity" model of human fertility. We find that the effect of the reform is large and statistically significant only for those households where neither parent is a citizen of an EU member state, which are those more likely to benefit from the change in legal status. We provide evidence that the obesity gap between preschool-aged children of noncitizens and citizens drops significantly for children born in 2000 or immediately afterward, compared to those born immediately before.

For most of the outcomes considered in this work, the change in the child's legal status at birth determines a convergence of immigrant fertility toward natives' levels. Therefore, our findings might also be explained, at least partially, by an increase in cultural assimilation caused by the reform.

Citizenship rights are often perceived as formal rights. Our results provide evidence instead that, when granted at birth, they can significantly increase the incentives of immigrant parents to invest in their children's human capital. These effects are likely to be stronger in countries where noncitizens have less economic opportunities.

\section{REFERENCES}

Aizer, Anna, and Flavio Cuhna. 2011. "Endowments, Investments and the Development of Human Capital." http://econweb.umd.edu/ davis/eventpapers/EndowmentsCunha.pdf.

Almond, Douglas, and Janet Currie. 2011. "Human Capital Development before Age Five." In Handbook of Labor Economics, Vol. 4, edited by Orley Ashenfelter and David Card, 1315-1486. Amsterdam: North Holland.

Almond, Douglas, Lena Edlund, and Kevin Milligan. 2009. "O Sister, Where Art Thou? The Role of Son Preference and Sex Choice: Evidence from Immigrants to Canada." National Bureau of Economic Research (NBER) Working Paper 15391. 
Anderson, Patricia M., Kristin F. Butcher, and Phillip B. Levine. 2003. "Maternal Employment and Overweight Children." Journal of Health Economics 22 (3): 477-504.

-Angrist, Joshua, Victor Lavy, and Analia Schlosser. 2010. "Multiple Experiments for the Causal Link between the Quantity and Quality of Children." Journal of Labor Economics 28 (4): 773-824.

Anil, Merih. 2006. "The New German Citizenship Law and Its Impact on German Demographics: Research Notes." Population Research and Policy Review 25 (5-6): 443-63.

- Avitabile, Ciro, Irma Clots-Figueras, and Paolo Masella. 2013. "The Effect of Birthright Citizenship on Parental Integration Outcomes." Journal of Law and Economics 56 (3): 777-810.

-Avitabile, Ciro, Irma Clots-Figueras, and Paolo Masella. 2014. "Citizenship, Fertility, and Parental Investments: Dataset.” American Economic Journal: Applied Economics. http://dx.doi.org/10.1257/ app.6.4.35.

-Becker, Gary S., and H. Gregg Lewis. 1973. "On the Interaction between the Quantity and Quality of Children.” Journal of Political Economy 81 (2 Pt. 2): S279-88.

Becker, Gary S., and Nigel Tomes. 1976. "Child Endowments and the Quantity and Quality of Children." Journal of Political Economy 84 (4 Pt. 2): S143-62.

Bertocchi, Graziella, and Chiara Strozzi. 2010. "The Evolution of Citizenship: Economic and Institutional Determinants." Journal of Law \& Economics 53 (1): 95-136.

Bevelander, Pieter, and Justus Veenman. 2006. "Naturalisation and Socioeconomic Integration: The Case of the Netherlands." Institute for the Study of Labor (IZA) Discussion Paper 2153.

Blau, Francine D., Lawrence M. Kahn, Albert Yung-Hsu Liu, and Kerry L. Papps. 2008. "The Transmission of Women's Fertility, Human Capital and Work Orientation across Immigrant Generations." National Bureau of Economic Research (NBER) Working Paper 14388.

-Bosswick,Wolfgang. 2000. "Development of Asylum Policy in Germany." Journal of Refugee Studies 13 (1): 43-60.

- Bratsberg, Bernt, James F. Ragan, Jr., and Zafar M. Nasir. 2002. "The Effect of Naturalization on Wage Growth: A Panel Study of Young Male Immigrants." Journal of Labor Economics 20 (3): 568-97.

Cameron, A. Colin, Jonah B. Gelbach, and Douglas L. Miller. 2008. "Bootstrap-Based Improvements for Inference with Clustered Errors." Review of Economics and Statistics 90 (3): 414-27.

-Card, David, Carlos Dobkin, and Nicole Maestas. 2009. "Does Medicare Save Lives?" Quarterly Journal of Economics 124 (2): 597-636.

Cawley, John, and Feng Liu. 2007. "Maternal Employment and Childhood Obesity: A Search for Mechanisms in Time Use Data." National Bureau of Economic Research (NBER) Working Paper 13600.

Datar, Ashlesha, M. Rebecca Kilburn, and David S. Loughran. 2010. "Endowments and Parental Investments in Infancy and Early Childhood." Demography 47 (1): 145-62.

DeVoretz, Don J., and Sergiy Pivnenko. 2004. "The Economic Causes and Consequences of Canadian Citizenship.” Institute for the Study of Labor (IZA) Discussion Paper 1395.

Dumont, Jean-Christophe, and Gilles Spielvogel. 2008. International Migration Outlook: Annual Report 2008 Edition. Organisation for Economic Co-operation and Development (OECD). Paris, November.

-Dustmann, Christian. 1999. "Temporary Migration, Human Capital, and Language Fluency of Migrants." Scandinavian Journal of Economics 101 (2): 297-314.

Dustmann, Christian, and Josep Mestres. 2011. "Savings, Asset Holdings, and Temporary Migration.” Institute for the Study of Labor (IZA) Discussion Paper 5498.

-Fernández, Raquel, and Alessandra Fogli. 2009. "Culture: An Empirical Investigation of Beliefs, Work, and Fertility." American Economic Journal: Macroeconomics 1 (1): 146-77.

-Fertig, Angela, Gerhard Glomm, and Rusty Tchernis. 2009. "The Connection between Maternal Employment and Childhood Obesity: Inspecting the Mechanisms." Review of Economics of the Household 7 (3): 227-55.

-Fougere, Denis, and Mirna Safi. 2009. "Naturalization and Employment of Immigrants in France (1968-1999)." International Journal of Manpower 30 (1/2): 83-96.

Gelber, Alexander, and Adam Isen. 2013. "Children's Schooling and Parents' Behavior: Evidence from the Head Start Impact Study." Journal of Public Economics 101: 25-38.

-Goodman, Robert. 1997. "The Strengths and Difficulties Questionnaire: A Research Note." Journal of Child Psychology and Psychiatry 38 (5): 581-86.

Huntington, Samuel P. 2004. Who Are We? America's Great Debate. Berkshire, United Kingdom: Free Press.

Kleiser, Christina, Angelika Schaffrath Rosario, Gert B. M. Mensink, Reinhild Prinz-Langenohl, and Bärbel-Maria Kurth. 2009. "Potential Determinants of Obesity among Children and Adolescents in Germany: Results from the Cross-Sectional KiGGS Study." BMC Public Health 9: 46. 
Labree, L. J., H. van de Mheen, F. F. Rutten, and M. Foets. 2011. "Differences in Overweight and Obesity among Children from Migrant and Native Origin: A Systematic Review of the European Literature." Obesity Review 12 (5): e535-47.

Lee, David S. 2009. "Training, Wages, and Sample Selection: Estimating Sharp Bounds on Treatment Effects." Review of Economic Studies 76 (3): 1071-1102.

Mastrobuoni, Giovanni, and Paolo Pinotti. 2010. "Migration Restrictions and Criminal Behavior: Evidence from a Natural Experiment." http://dev3.cepr.org/meets/wken/2/2413/papers/Pinotti.pdf.

Mayer, Jochen, and Regina T. Riphahn. 2000. "Fertility Assimilation of Immigrants: Evidence from Count Data Models." Journal of Population Economics 13 (2): 241-61.

Mazzolari, Francesca. 2009. "Dual Citizenship Rights: Do They Make More and Richer Citizens?" Demography 46 (1): 169-91.

Mueller, Claus. 2006. "Integrating Turkish Communities: A German Dilemma." Population Research and Policy Review 25 (5-6): 419-41.

Popkin, Barry M., and J. Richard Udry. 1998. "Adolescent Obesity Increases Significantly in Second and Third Generation U.S. Immigrants: The National Longitudinal Study of Adolescent Health." Journal of Nutrition 128 (4): 701-06.

-Ravens-Sieberer, U., and M. Bullinger. 1998. “Assessing Health-Related Quality of Life in Chronically Ill Children with the German KINDL: First Psychometric and Content Analytical Results." Quality of Life Research 7 (5): 399-407.

- Riphahn, Regina T., Monika Sander, and Christoph Wunder. 2013. "The Welfare Use of Immigrants and Natives in Germany: The Case of Turkish Immigrants." International Journal of Manpower 34 (1): 70-82.

- Rosenzweig, Mark R., and Junsen Zhang. 2009. "Do Population Control Policies Induce More Human Capital Investment? Twins, Birth Weight and China's 'One-Child' Policy.” Review of Economic Studies 76 (3): 1149-74.

- Ruhm, Christopher J. 2004. "Parental Employment and Child Cognitive Development." Journal of Human Resources 39 (1): 155-92.

Sarrazin, Thilo. 2010. Deutschland schafft sich ab. Munich: Deutsche Verlags-Anstalt.

Steinhardt, Max Friedrich. 2008. "Does Citizenship Matter? The Economic Impact of Naturalizations in Germany." Centro Studi Luca d'Agliano Development Studies Working Paper 266.

von Hinke Kessler Scholder, Stephanie. 2008. "Maternal Employment and Overweight Children: Does Timing Matter?" Health Economics 17 (8): 889-906.

-Will, Beata, Hajo Zeeb, and Bernhard Baune. 2005. "Overweight and Obesity at School Entry among Migrant and German Children: A Cross-Sectional Study.” BMC Public Health 9: 45. 